\title{
The arbitration of nature: state, water, and civil engineering in Northern Ireland directly after partition
}

\author{
Michael Reinsborough ${ }^{1,2,3}$ (D)
}

Received: 7 December 2020 / Accepted: 10 September 2021 / Published online: 10 October 2021

(c) The Author(s) 2021

\begin{abstract}
Begun in the summer of 1923, the Silent Valley Reservoir was the first large scale civil engineering project after the division between the North and the South of Ireland. It was the continuation of a previous project. In the late Nineteenth Century a portion of the Kilkeel and Annalong Rivers in the Mourne Mountains had been diverted 35 miles to provide water for the growing industrial city of Belfast in the North of Ireland. A reservoir in the mountains was also planned at a later date but this was delayed by the Great War and then by Irish political instability and the high cost of construction in immediate post war period. Before being completed the project had to overcome several obstacles. Firstly, the Mourne Mountains were claimed by the South of Ireland and thus subject to the Boundary Commission of the Anglo-Irish peace treaty. The Water Commissioners had brought important British political leaders to tour the Silent Valley construction site in an attempt to demonstrate how implausible a situation (in their opinion) that the South should control the major water supply to the capital city of the North. Secondly, shortly after the Boundary Commission was shelved, the combination of fluid subsoil and the failure to locate bedrock at expected depth brought construction to a halt while an engineering, political, and legal solution was sought for the expensive and now publicly controversial project. This article traces the contingent relationship between state (sovereignty) and technology (water reservoir) using a socio legal and socio material description of the crucial arbitration process enabling further time and resources for resolution of the difficulty. Ultimately an air-shaft device for excavating under increased atmospheric pressure had to be designed taking in mind both technical and political difficulties. Today the 3000-million-gallon reservoir, first imagined in the late Nineteenth Century, continues to be a major water source for the city of Belfast.
\end{abstract}

Keywords Water history $\cdot$ Northern Ireland $\cdot$ Sovereignty $\cdot$ Legal studies $\cdot$ Actor-network theory $\cdot$ Performance $\cdot$ Technology $\cdot$ Devices

Michael Reinsborough

michael.reinsborough@uwe.ac.uk

1 Department of Health and Social Sciences, University of the West of England, Bristol BS16 1QY, UK

2 BrisSynBio, University of Bristol, Life Sciences Building, Tyndall Avenue, Bristol BS8 1TQ, UK

3 School of Oriental and African Studies (SOAS), University of London, Thornhaugh Street, Russell Square, London WC1H 0XG, UK 
SIR LYNDEN MACASSEY—Are you ready, sir?

THE ARBITRATOR-Yes.

SIR LYNDEN MACASSEY - Sir, as you probably know from the submission to you in this case this is an Arbitration between S. Pearson \& Son (Contracting Department) Ltd., and the Belfast Cityand District Water Commissioners. I hardly like to call it a dispute. It really is an application to you for the purpose of arriving at some solution to difficulties in connection with the contract between Messrs Pearson and the Belfast Water Commissioners for the construction of a Reservoir in the Silent Valley. ${ }^{1}$

With this modest exchange, the arbitration proceedings-rather optimistically characterised by the representative for the plaintiff as hardly a dispute- - began on Monday morning 13th December 1926. The arbitration regarded the construction difficulties at the Silent Valley Reservoir project. The reputation of both parties, contractors and Water Commissioners, were at stake. Belfast water ratepayers disliked the expensive project. Its previous invocation by the Water Commissioners during the Boundary Commission dispute, made the project particularly controversial along a polarized nationalist/unionist line of tension in the province directly after partition and very recent violent conflict. The project was thus subject to possible cancellation in the event of an acrimonious dispute, a situation which neither the Water Commissioners nor the contractors desired. And this is perhaps why the barrister for the contractor chose to downplay the crisis.

Begun in the summer of 1923, the Silent Valley Reservoir was the first large scale civil engineering project after the division between the north and the south of Ireland (Fig. 1). It was also the continuation of a previous project. In the late nineteenth century, a portion of the Kilkeel and Annalong Rivers in the Mourne Mountains had been diverted 35 miles to provide water for the growing industrial city of Belfast in the north of Ireland. A reservoir in the mountains was also planned at a later date but this was delayed by the Great War and then by Irish political instability plus the high cost of construction in the immediate post war period.

Before being completed, the Silent Valley Reservoir project had to overcome several obstacles. Firstly, the Mourne Mountains were claimed by the South of Ireland and thus subject to the Boundary Commission of the Anglo-Irish peace treaty. The Water Commissioners had brought important British political leaders to tour the Silent Valley construction site in an attempt to demonstrate how implausible a situation would be that the South should control the major water supply to the capital city of the North. The boundary crisis was deferred by assigning a commission which would report back, but ultimately never did. The report was leaked in 1925 but disclaimed, thus consolidating the existing arrangement of boundary. Gramscian historians Bew, Patterson and Gibbon write, “...the state of Northern Ireland began in 1921 or between 1921 and 1925 when the boundary commission was laid to rest". 2 The importance of the Boundary Commission shouldn't be understated. The viability of the fledgling state required a boundary which maintained a unionist electoral majority (i.e., primarily Protestant), retained areas vital to its economic

\footnotetext{
1 "Report of the Arbitration Proceedings, 13th December 1926", Water Commissioners' Papers, WAT/1/3E/1/8 Public Record Office of Northern Ireland (PRONI), Belfast.

2 Bew et al. (1979) The State in Northern Ireland 1921-1972: Political Forces and Social Classes Manchester: Manchester University Press. More recent editions of this book also include this remark but they downplay the original Gramscian analysis of the early state.
} 
viability (for example the linen mills region south west of Belfast), and retained control of vital resources (water). Secondly, as the Boundary Commission was deliberating, the combination of fluid subsoil and the failure to locate bedrock at expected depth brought construction to a halt while an engineering, political, and legal solution was sought for the expensive and soon to be publicly controversial project.

Why hasn't existing historiography of the Silent Valley reservoir identified this possible threat to the viability of early Northern Ireland? ${ }^{3}$ In part this might have been the skillful silence of the architects of the Silent Valley Reservoir downplaying potential crisis or vulnerability, while they played out a timing in which the boundary and reservoir difficulties did not collide. In part this may have been the outcome of a skillful legal resolution about the resources and time necessary to determine whether the reservoir was viable in the face of fluid sub-soil excavation difficulties.

As this article will show, the legal solution was grounded in the materiality of the subsoil (nature) and also, of note, procedurally grounded in the materiality of the contract (legal sovereignty). Ultimately an air-shaft device for excavating under increased atmospheric pressure would be designed taking in mind both technical and political difficulties. Today the 3000-million-gallon reservoir, first imagined in the late nineteenth century, continues to be a major water source for the city of Belfast. However, this article will focus on a very specific moment of this water history in the arbitration chamber, a sort of micro water history of three days. ${ }^{4}$

Because of the sub-soil, the design was said to be unfit for purpose-which made the Water Commissioners responsible for solving the problem, because they were responsible for errors of design according to a particular reading of the contract. This particular arrangement of the facts enabled the contractors to force renegotiation of the legal and financial provisions. Although they wanted to find a solution to the excavation difficulties they did not want to pay out of their own pockets. The contractors' legal team, represented in the arbitration hearings by Sir Lynden Macassey, tried to connect a dispute at the level of nature to an arrangement of forces in the legal and political arena without directly challenging the sovereign interests of the Northern Ireland or their delegates the Water Commissioners. Before turning directly to the legal dialogue, I review some of the issues at stake and provide scholarly background.

\footnotetext{
3 The most prominent works on the Silent Valley Reservoir are a celebratory commissioned study published shortly after completion and a 1970s nostalgic account based on elderly interviews of those who constructed the reservoir. A more recent piece by PTA Donald notes implicit blame that has emerged from earlier histories of the Silent Valley Reservoir. Margaret O'Callaghan notes the issue of water in the boundary debates. Loudan (1940) In Search of Water: being a history of the Belfast Water Supply Belfast: Belfast City and District Water Commissioners; Carson (1981) The Dam Builders: The Story of the Men who Built the Silent Valley Reservoir Mourne Observer Press; P.T.A. Donald (2012) "The Silent Valley dam: setting the record straight" Engineering History and Heritage 165 May 2012 Issue EH2 pp. 81-92 http://dx.doi. org/10.1680/ehah.11.00014; O'Callaghan (2000). 'Old Parchment and Water'; the Boundary Commission of 1925 and the Copperfastening of the Irish Border. Bullan; an Irish Studies Journal, 5(2), 27-55.

${ }^{4}$ For a description of microhistories see Ginsberg (1993) "Two or Three Things I know about Microhistory" translated Tedeschi and Tedeschi, Critical Inquiry 10:1 pp. 10-35. I do not provide a "history of mentalities' except in as much as I speculate on motivations of actors within the arbitration and I only weakly link the case to the broader contexts, but the emphasis on how the micro and macro scales interact is broadly a theme of this article.
} 
Fig. 1 Map printed and distributed by the Water Commissioners during boundary debates in 1924,2 years prior to the arbitration. Evidence such as this, said to be "non-political" by the Water Commissioners, was seen by others as opposinng any changes in the boundary of Northern Ireland and thus aligning with unionist rather than nationalist interests. Source: scanned image

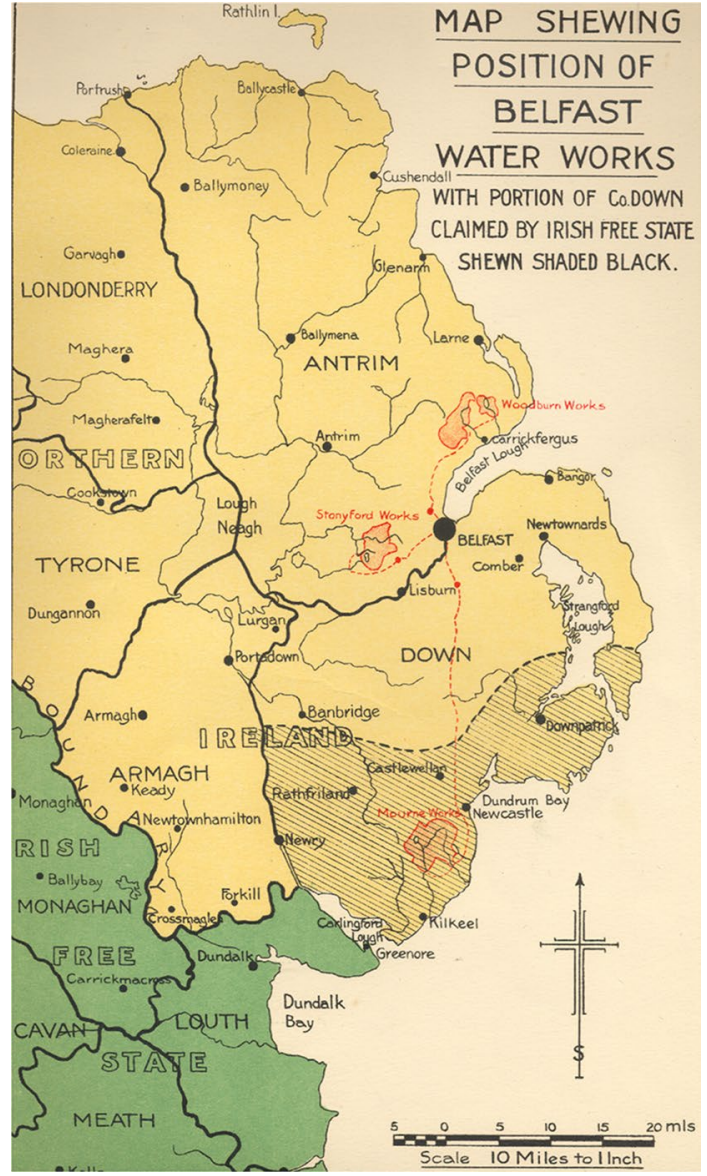

\section{History, technology and sovereignty}

Certain moments in history are worth telling closely because they seem to illustrate contingency, that is, that perhaps the story could have gone very differently. It is for this reason I tell what ultimately is a water history through a very particular lens, the contract dispute which seems to be one of its most contingent moments. For the historian exploring how the design of technological objects relate to the social and political circumstances of their design (and vice versa), this example provides a plausible opportunity to investigate what, if any, relations exists between state and technology. ${ }^{5}$ Does the boundary dispute (a struggle establishing local state sovereignty over a specific territorial region) influence the design/construction of technological objects (for example the reservoir, the air-shaft device, or other technical processes related to reservoir construction)? Did reservoir construction

\footnotetext{
5 Some previous work on this issue includes Carrol (2006) Science, Culture, and Modern State Formation Berkeley and Los Angeles: University of California Press. This question is also longstanding within water history.
} 
within the disputed territory influence that dispute? In this article I will demonstrate a relationship between science and sovereignty, albeit a necessarily contingent one. Science and sovereignty normally operate on very different social scales: states are measured in territory and laboratories in square footage. Laboratories are always in process. Sovereignty is normally fully established. Because of the relative size and importance of this water project to the fledgling state, and the formative and in-question character of the sovereignty at this early moment in Northern Ireland's history, a plausible argument about the connection between these two differing elements of micro and macro social scale can be shown. ${ }^{6}$ It is because a fledgling state encountered a world-class engineering problem in a project directly related to its sovereign interests that the Silent Valley reservoir contract litigation is salient for water history.

Perhaps because it is located between governance and engineering, water history has more recently become an increasingly important topic in social histories of technology in the past decade. Both the editorial of a special issue of Technology and Culture dedicated to water (2008), and the launch editorial of the new international journal Water History (2009) comment on this. ${ }^{7}$ John Broich, one example among many, writes the nineteenth century history of water in London linking municipal and parliamentary politics in arguments over who should update and control the water supply. ${ }^{8}$ The public works project links engineer and technical details of organizing some aspect of environment to the greater realm of culture and politics through the means of public funding (and all the public dialogue, common purpose debates, and political negotiations necessary to authorize such funding).

Early historical material on dams and reservoirs tended to focus either on the development of reservoir design (often written by engineers) or on the bureaucratic politics of water authority institutions. ${ }^{9}$ One historian in the latter category emphasized "...the relation of hydraulic construction to social and economic necessities and to military conquest" in the great ancient civilizations. ${ }^{10}$ Even if political historians of empire have largely

\footnotetext{
${ }^{6}$ Early discussions of reconciling social scale description (micro/macro) can be found in Knor-Cettina (1981) Advances in Social Theory and Methodology: Toward an integration of micro- and macro-sociologies Boston, London and Henley: Routledge and Kegan Paul.

7 Reuss (2008) "Seeing Like an Engineer: Water Projects and the Mediation of the Incommensurable", Technology and Culture 49:3:531-549; Templehoff et al. (2009) "Where has the water come from?" Water History 1:1:1-8.

${ }^{8}$ Broich (2013) London: Water and the Making of the Modern City Pittsburg: University of Pittsburgh Press.

9 Examples of work in the latter are Hundley (1975) Water and the West Berkeley: University of California Press; Hundley (1992) The Great Thirst: Californian Water 1770s-1990; Berkeley: University of California Press; Worster (1985) Rivers and Empire: Water, Aridity, and the Growth of the American West New York: Pantheon. Examples of the former Smith (1972) A History of Dams Seacaucu, N.J.: Citadel Press; Smith (1975) Man and Water New York: Schribner's Sons; and Schnitter (1994) A History of Dams: The Useful Pyramids Rotterdam:A.A. Balkema. Smith in particular set the academic standard for including social and cultural aspects of dam history. A good example of the minority portion of the literature on dams which properly engages a social history of technology is Donald Jackson's interest in how "different designs might reflect varying interests and objectives on the part of engineers, financiers, and governments." Jackson (1995) "Review: A history of Dams", Technology and Culture 36:1:179-180, p. 180. For a more radical emphasis on the active role of water (or other natural forces) in the account of culture and (water) technology see White (1995) The Organic Machine: The Remaking of the Columbia River New York: Hill and Wang.

10 Conduit (1973) "Review: A History of Dams" Technology and Culture, 14:4:621:622, p. 622. Perhaps the most significant of the water history and civilization writings is The Despotic State by Karl Wittfogel. The Wittfogel thesis is normally understood as the idea that the construction of large irrigation projects required central authority and thus initiated the state. Wittfogel (1957), The Despotic State: A comparative
} 
neglected the role of technologies or seen them merely as tools for empire, historians of technology who emphasize the mutually inter-determining role of culture and technology have shown that empires require and develop particular technologies (some of which are water technologies) and that, in turn, particular technologies enable and shape empires. ${ }^{11}$ An object that functions by holding shape continuity as it moves from one spatial region to another (for example, the hull of a sailing ship that moves from Portugal to India), has been described as an immutable mobile. ${ }^{12}$ This is also to say that its components exist in a fixed actor-network $^{13}$ of relations to one another. The use of immutable mobiles has had great

\section{Footnote 10 (continued)}

study in total power New Haven: Yale University Press. Donald Worster is a more recent writer connecting big water projects to big power. Worster (1997) "Hoover Dam: A Study in Domination" in Jackson, Donald (ed) Dams: Studies in the History of Civil Engineering, Volume 4 Brookfield USA: Ashgate. A different reading of the Wittfogel thesis presents hydrology as the science most exemplary of the state's need to suppress and direct into conduits the active role of water (or other natural forces) in order to establish its sovereignty. Deleuze, and Guattari (1987) A Thousand Plateaus Minneapolis, London: Minneapolis University Press, p. 356. For a recent review of relevance of the Wittfogel thesis see Mori (2020) "'Water and power': what is left? An introduction to the workshop 'Waterscapes: new perspectives on hydrocultural landscapes in the ancient Near East" "Water History 12:11-22.

${ }^{11}$ Marsden and Smith (2005) Engineering Empires: A Cultural History of Technology in Nineteenth Century Britain Basingstoke: Palgrave Macmillan. In parallel discussion the role of science and empire has also been widely debated. See for example MacLeod (1997) "On Science and Colonialism" in Peter J. Bowler and N. Whyte, eds. (1997) Science and Society in Ireland: The Social Context of Science and Technology in Ireland 1800-1900 Antrim: Belfast Institute of Irish Studies QUB, or for an Irish specific example see Whyte (1997) "Science and Nationality in Edwardian Ireland" in the same volume. Whyte examines how the material practices of science (where will the type-specimens of Irish marine species be kept-in South Kensington or Dublin?) are deployed in support of contested nationality. Like myself, Patrick Carrol moves the Irish historiography of science and engineering from 'which state?' to 'how?' He uses the Irish case to conceive material practices of engineering as enacting the state form of organization. Government involvement in the improvement of land, construction of infrastructure always also had a moral objective of improving the population, rendering them governable, as well as being the material infrastructure by which the state is enacted. In a recent water history example (hydroelectric before and after the Mexican revolution) the author encourages examination of "nonnormative processes of state formation" where the interrupted relations of water and state can provide insight. Carroll-Burke (2002) "Material Designs: Engineering Cultures and Engineering States-Ireland 1650-1900" Theory and Society 31:1:75-114; Hill (2017) "Circuits of State: Water, Electricity, and Power in Chihuahua, 1905-1936" Radical History Review 127:13-39 (January) p. 30. For an early description of state and nature-shaping see Mukerji (1994) "The political mobilization of nature in seventeenth century French formal gardens" Theory and Society 23:5:651-677.

12 The example is drawn from Law (1987) "Technology and Heterogeneous engineering: The Case of Portuguese Expansion" in Bijker, Wiebe E., Thomas P. Hughes and Trevor J. Pinch The Social construction of technological systems: new directions in the sociology and history of technology Cambridge, MA: MIT Press. The term immutable mobile is used by Latour (1999) Pandora's Hope: Essays on the Reality of Science Studies Cambridge, MA, London, UK: Harvard University Press, pp. 102, 306-307.

${ }^{13}$ An 'actor-network' replaces the 'actor' of social theory with a distributed network of things/persons from which agency is said to emerge. Sailors with a hull, mast, rigging, sails, open waters and cannons, were able to be agents of Portuguese expansion at least while the hull part of this network remained intact in relationship to the smooth or stormy ocean part. Social interactionism and especially ethnomethodology emphasized that there is no fixed structure to human society within which social agents act but instead structure emerges from social interaction. Harold Garfinkle (1967) Studies in Ethnomethodology Cornwall: Prentice Hall. While actor-network theory (ANT) built upon this type of approach to the structure/agency question in sociology it also pointed out the previous lack of emphasis on the material aspects of social interaction (tool use, strategic deployment of features in the environment, material artefacts of culture, etc.) in much of sociology and anthropology. For this reason, ANT is potentially of interest to the historian of technology. The term 'actor-network theory' was coined by Law (1992) "Notes on the Theory of the Actornetwork: Ordering, Strategy, and Heterogeneity" Systems Practice 5:179-393. For an early example see 
significance for the expansion of European culture, colonialism and scientific influence. The actor-network theorist attempts to show how the device used to resolve a social-political-technical problem (for example, the air-shaft device ${ }^{14}$ ) is shaped by political-social concerns. This shaping allows the device in subsequent performances or different places to reiterate its social or political function. When taking up this research this was initially the conceptual framework that I sought to employ. ${ }^{15}$ Because our linguistic conventions divide the 'social' from the 'technical' this can be difficult to reveal when latent function emerges in conjunction with a social convention. ${ }^{16}$ By closely examining the circumstances of the legal dispute, I describe how the performance of an instance of legal convention enables the device which ultimately solves the problem. ${ }^{17}$ While linking law and engineering disputes is hardly new, I further trace the science within engineering to the sovereignty within law to build a more suggestive description of the contingent relationship between state (sovereignty) and technology (water reservoir).

Law is one of the key institutions of the state, both procedurally and as a legitimating factor. Because the sovereign power is said to establish the law, even mundane procedures of law can be said to be grounded in state sovereignty. While much of coming to a decision can be procedural, i.e., governed by law, there will also arise circumstances where a certain amount of judgement must be applied. The procedural sovereignty of law can be interrogated for the influence of actors and circumstance. The archival method I use closely looks at the socio-legal performance of the law. By reading the different parties accounts against one another I provide for a very close reading of the circumstances and particular occasion of dispute. ${ }^{18}$ As this methodology demonstrates, the archival record of legal conflict is a

Footnote 13 (continued)

Callon (1986) "Some Elements of a Sociology of Translation: Domestication of the Scallops and the Fishermen of St Brieuc Bay" in Law (1986) Power, Action, Belief London: Routledge.

14 For a strictly technical description of air-shaft design see McIldowie (1934) The Construction of the Silent Valley Reservoir, Belfast Water-Supply London: The Institution of Civil Engineers, available in the McClay Library, Special Collections, Queen's University Belfast.

15 Since first presenting an earlier version of this work in conference more water historians have also discovered this approach. See Maurits Ertsen (2016) "A matter of relationships: Actor-networks of colonial rule in the Gezira irrigation system, Sudan." Water Alternatives 9(2): 203-221; A similar approach, but using the terminology 'devices', is used by Ballaestro (2019) in her suggestively named book A Future History of Water U.S.A.: Duke University Press; For the social theory term 'devices' see John Law and Evelyn Ruppert (2013) “The Social Life of Methods: Devices” Journal of Cultural Economy 6:3:229-240.

16 Sociologists of technology speak of the 'interpretive flexibility' of a device, that it can be used differently in different social situations. Thus, the sceptic can always say, yes, but the device doesn't inherently do that. That is just its effect within one social group or under the regime of a particular social convention. In return the actor-network theorist would have to demonstrate that selection, application, or development of the device was because of or influenced by this regime of convention. But by this time the sceptic has already moved on. For 'interpretive flexibility' see Pinch and Bijker (1984) "The Social Construction of Facts and Artifacts" Social Studies of Science 14:399-441.

17 The term 'device' I take from 'airshaft device'. Both convention (social) and device (material) are 'devices' in the social theory sense of the term (i.e., repeatable things which a social actor can deploy to do or accomplish something). Social conventions examined closely usually have some material support. Reciprocally, material devices have social conventions associated with their use.

18 The close reading methodology is not dissimilar to that of literary criticism with an emphasis on critical reading, to read against the grain of actors' narratives, locating their interests in their contrasting presentations, emphasis, and arrangement of the facts, each representing the same situation differently. To the limited extent that socio-legal or political interpretive method was necessary I have relied upon relational (feminist) theories of contract, Mark Suchman's incorporation of actor-networks into a description of material practices of contract (as a social and technical object), and Bob Jessop's classic account of the relationship between jurisprudence and state sovereignty. Wheeler (2005) Feminists Perspectives in Contract Law London: Taylor and Francis; Mulcahy (2008) Contract Law in Perspective 5th Edition New York: Rout- 
location in which a more nuanced account of the everyday engineering challenges becomes worthy of preservation in the historical record.

The term 'sovereignty', which is more common in political science or socio-legal studies, I bring into water and technology history. ${ }^{19}$ Political theorist Mark Neocleous notes the term transitioned from court rule in the name of a monarch into more recent governing systems. ${ }^{20}$ Sovereignty is the power of interlocking institutions or a system of governance to come to a decision and assert itself in the name of the 'state'. Max Weber, following earlier writers such as Leo Tolstoy, grounds the power of the state in violence: the state is a "human community that ... claims the monopoly of physical force within a given territory." 21 Thus territory and potential for violence can be associated with state sovereignty. Theories of sovereignty vary considerably. For Karl Schmitt sovereignty lies with he who decides the exception within the law (for example, use of extra-constitutional violence by the state) which maintains and reproduces the legal system across points when formal procedures and the requirements of reality seem (to Schmitt at least) to conflict. ${ }^{22}$ For political theorist Giorgio Agamben, describing the biopolitics of the early twentieth century, the 'exception' which the sovereign arbitrates is the exclusion or ban of some types of life from political consideration. Agamben sees this as happening when the factual level of life is given over to political power (by the sovereign exception). Says Agamben, "The fundamental activity of sovereign power is the production of bare life as originary political element and as threshold of articulation between nature and culture." ${ }^{23}$ His work can be used to think about how political sovereignty is relevant to this case study. When political theorists such as Agamben and Neocleous define sovereignty in its ability to ban or exclude, we can make a significant link between sovereignty and the world-establishing experimental method for determining facts about nature, for distinguishing subjective opinions from objective knowledge. Scientific judgement, in a specific situation, bans alternative interpretations. In the seventeenth century Robert Boyle provided legitimacy for the newly created experimental science method by emulating the legal conventions of witnessing treason against the sovereign. ${ }^{24}$ The laws of science were explicitly modelled on the laws of the sovereign.

\section{Footnote 18 (continued)}

ledge-Cavendish, pp. 42-45; Suchman (2003) "The Contract as Social Artifact" Law and Society Review 37:1:91-142; Jessop (1990) "Recent Theories of Law, the State, and Juridico-Political Ideology" in Jessop (1990) State Theory: Putting the Capitalist State in its Place UK: Polity Press. On the importance of the performative in history see Burke (2005) "Performing History: The Importance of Occasions" Rethinking History 9:1:35-52.

19 As I discuss below, water history typically engages with sovereignty as a concept of international law when watersheds cross state boundaries. In the Silent Valley case the waterscape is fixed but the international boundary threatens to fluctuate or flow across the watershed.

20 Neocleous (2003) Imagining the State, Maidenhead, UK and Philadelphia, USA: Open University Press.

21 Weber (2004 [1919]) "Politics as a Vocation" in Owen, David and Strong, Tracy B. (eds.) Max Weber: the vocation essays: "science as a vocation", "politics as a vocation", Indianapolis, USA: Hackett; Tolstoy (1984 [1894]) The Kingdom of God is Within You: Christianity Not as a Mystic Religion but as a New Theory of Life. Trans: Constance Garnett. Lincoln, NE: University of Nebraska Press, p. 166.

22 Schmitt (1985) Political Theology: Four Chapters on the Concept of Sovereignty Cambridge: MIT University Press.

23 Agamben (1998) Homo Sacer: Sovereign Power and Bare Life Stanford: Stanford University Press.

24 Shapin and Schaffer (1985) Leviathan and the air-pump: Hobbes, Boyle, and the experimental life (Vol. 109). Princeton University Press, p. 327. 
To operationalise this conceptual framework I specifically discuss three levels of sovereignty: (1) state sovereignty, (2) the procedural sovereignty of law (contract arbitration process), and what I will call (3) scientific sovereignty or expertise which occurs when an engineer/arbitrator is asked to pass judgement on the nature of an unknown material. In order to describe the relation between these three, I use a simple operational definition of sovereignty: the term is intended to mean the ability to make a decision, particularly over some question of common dispute. The empirical details available in the civil engineering legal record are a place to look for links between the ability to make decisions in an engineering dispute and the ability of that much larger sociological unit, the state, to come to a decision (sovereignty).

It is suggestive that the term 'civil engineering' was only taken up first in the eighteenth century, previous to which the very same tasks were done by military engineers. ${ }^{25}$ The ironic origin of the 'civil' within the martial powers of sovereigns and city-states suggests the interconnection not just of nature and civil engineering, but also of political sovereignty. State action to improve nature (the building of roads, the drainage of bogs, moral improvements to the nature of the citizenry such as through the building of schools or hospitals) have extended the political reach of the state. ${ }^{26}$

Previous work on sovereignty in recent water history has naturally focused on state sovereignty in an international legal context. Tvedt, McIntyre and Woldetsadik, in their editors' article introducing History of Water, Series III, Volume 2: Sovereignty and International Water Law, point out the Westphalian Treaty (the mythical origin of the state form of social organisation) gave explicit reference to cooperation in common interest over the Rhine River which flowed through the numerous principalities in question. They suggest it is.

the particular 'rules of the games' in the particular river basin that should be properly analysed in order to avoid conflict and promote further cooperation. Resolution of water conflict is, therefore, essentially a negotiation of particular linkages, of which the particular geographical and hydrological linkages are but two. ${ }^{27}$

Knowledge practices do not explicitly form a part of their argument. Verhoven's study of Islamic state power imagined through dam construction does a little to connect sovereignty to science by tracing a mentality historically back to Napoleon's 'savants' who articulated a grand vision for Egyptian agriculture (resulting in the British constructed Aswan Dam), which Sudan hoped to emulate. ${ }^{28}$ Gilmartin's account of the India Pakistan river basin debate shows the social forces in play and documents Pakistan's hasty reorganisation of water policy after the river diversion to protect their state interest in distributing better

\footnotetext{
25 Joyce Brown in series preface to Jackson (1997) Dams: Studies in the History of Civil Engineering, Volume 4 Brookfield, USA: Ashgate, p. xiii.

${ }^{26}$ Carroll-Burke (1992) "Material Designs: Engineering Cultures and Engineering States-Ireland 16501900", Theory and Society, 31/1:75-114 (February).

27 Tvedt et al. (2015) "Sovereignty, the Web of Water and the Myth of Westphalia" in Tvedt, McIntyre and Woldetsadik (eds) A History of Water Series III, Volume 2, Sovereignty and International Water Law London, New York: I.B. Tauris p. 17.

28 Verhoeven (2015) Water, Civilization and Power in Sudan: The Political Economy of Military-Islamist State Building Cambridge: Cambridge University Press. For a similar analysis of Egyptian water and science see Cookson-Hills (2013) "The Aswan Dam and Egyptian Water Control Policy, 1882-1902" Radical History Review 116:59-85.
} 
what water they had left. They turn to hydrology to reconstruct their capabilities. ${ }^{29}$ Many recent water histories have included a more nuanced account of the social role of science in hydro-engineering projects. In addition to its traditional instrumental value in designing projects, these histories document some failures of science, particularly grand vision colonial science, in achieving expected results, or maintaining those results over the longer environmental and cultural time period. Science creates 'normal water', 'modern water' and 'water as a neutral entity'. ${ }^{30}$ In environmental histories the technocratic failure to acknowledge the co-production of society and environment engenders the prescription (no doubt wise) to swap a political economy analysis for a political ecology. Soll's Empire of Water explicitly documents the favourable impact of testimony by New York City's chief water engineer in influencing the Supreme Court's decision in the 1931 Delaware River case without more than comment. ${ }^{31}$ While recent water history takes up the role of knowledge production, linking this to sovereignty is usually not considered, either by omission, by being legitimately outside the author's argument, or by being, as this article shows, not easily demonstrated without close attention to detail.

My attention to the articulation of sovereignty by local actors within their local engineering contexts is consistent with the approach advocated by Lauren Benton. Instead of thinking of sovereignty solely in terms of cartographic imaginaries and territorial control, the technology historian in the legal archive might remember that "sovereignty in empire formed as multiple agents positioned themselves to act as subjects of and proxies for imperial powers, and as polities and populations negotiated scope for their own autonomy, sometimes urging radical reconfiguration of rule." 32

Before turning directly to the legal dialogue, I review the origins of the reservoir and place it within the context of the Irish dispute.

\footnotetext{
${ }^{29}$ Gilmartin (2015) Blood and Water: The Indus River Basin in Modern History Oakland, California: University of California Press.

${ }^{30}$ Schmidt (2017) Water: Abundance, Scarcity and Security in the Age of Humanity New York: New York University Press; Linton (2010) What is Water: The history of a modern abstraction Vancouver, Toronto: UBC Press; Ertsen (2011) "Book Reviews" Water History 3:1:63-66.

${ }^{31}$ Soll (2013) Empire of Water Ithaca, NY; London, UK: Cornell University Press, pp. 86-87.

${ }^{32}$ Benton (2009) Search for Sovereignty: Law and Geography in European Empires, 1400-1900. Cambridge: Cambridge University Press, p. 279. Benton's attention is only to sovereignty, not science. Conversely, several historians do not look at sovereignty but do emphasize the localized interpretation of technological objects to become "creole technologies" through "creative appropriation". In water history attention to new engineering techniques responding to specific agriculture practices in the colonial setting is provided by Ertsen. Edgerton (2007) "Global Histories: Rethinking now, travel in space and time," Journal of History of Science and Technology, 1:75-112; Dikkotter (2007) Things Modern: Material culture and everyday life in China. London: Hurst; Arnold (2013) Everyday Technology: Machines and the Making of India's Modernity University of Chicago Press; Ertsen (2010) Locales of Happiness: Colonial Irrigation in the Netherlands East Indies and Its Remains, 1830-1980 VSSD. Mariana Dudley describes how local configurations of Scottish island people and wind reshaped British energy policy to be included in the national rural electricity promise given by centralized authority. Her additional emphasis on materiality and environment (as well as local people and energy innovation) makes her argument closer to the one put forward here. Dudley (2019) "The Limits of Power: Wind Energy, Orkney, and the Post-war British State" Twentieth Century British History, 0:0:1-24; Terje Tvedt notes the role of new hydrological estimates changing the British negotiating position in the lead up to the Nile Waters Agreement. Terje Tvedt (2015) "Water Systems, Water Agreements, and State Sovereignty: The Case of the Nile Waters Agreement of 1929" in Tvedt, McIntyre and Woldetsadik (eds) A History of Water Series III, Volume 2, Sovereignty and International Water Law London, New York: I.B. Tauris, p. 611.
} 


\section{Reservoir design, early construction, and the Irish boundary dispute}

In 1891 Luke Macassey, chief engineer for the Belfast Water Commissioners (with a then young engineer Frederick W. McCullough as his assistant) selected and surveyed a catchment valley in the Mourne Mountains, County Down. He gave the valley its name for parliamentary legislation, ${ }^{33}$ designed the reservoir and diversion scheme, and then supervised construction of the initial portion: diversion of the Kilkeel and Annalong Rivers to supply the industrial city of Belfast.

After 1908 when the senior Macassey had passed away, McCullough took the role of chief engineer and began plans for the next stage of the Mourne water scheme, the reservoir, resurveying the valley and drawing up detailed design plans to put out to tender. ${ }^{34}$ The Great War, Irish political instability, and then the high cost of construction immediately after the war delayed construction. Eventually a contractor was selected. Construction began shortly after that in 1923 .

The roots of Irish partition began in the $19^{\text {th }}$ Century with agitation for home Rule in Ireland which was at that time governed by the British Parliament. In 1885 parliamentarians elected from Ireland to the British House of Commons suddenly held the balance of power between the liberals and the conservatives, neither one of which had an overall majority. They convinced the liberals to introduce a home rule bill, by which Ireland, within the British Empire, would govern itself. The bill was defeated and more narrowly stopped again in 1892. Within the northern province of Ireland, Ulster, the political dynamics began to change as Belfast liberals and conservatives joined together as unionists opposing nationalism for Ireland and gradually shifting to accept a partition strategy if home rule was inevitable.

The possibility of a third home rule bill brought about huge resistance in 1912 when 500,000 Ulster unionists signed the Ulster Covenant pledging to defy any Irish government. 25,000 rifles were secured, and British army officers threatened to resign rather than deploy against the Ulster Volunteers. An amendment to the bill excluding Ulster was being debated when the First World War broke out in August 1914. In 1916 the Easter Rising in Dublin was crushed by the British but succeeded politically. Except in Ulster, the Irish elections of 1918 validated the party of nationalists seeking a united Ireland outside the British Empire. They proceeded to set up an independent parliament, the Dáil Éireann, thus setting off the Anglo-Irish war. The British Government presented a home rule bill creating two separate devolved governments, the northern one consisting of six counties within which the Ulster unionists could expect an electoral majority. They would promptly vote to re-join the union. This partition formed the substance of the Anglo-Irish peace treaty negotiated by British Prime Minister David Lloyd-George.

Thus between initial conception and reservoir initiation, the partition of Ireland brought about by war had changed the arrangements of governance. There were now two separate states. The Boundary Commission was a requirement from negotiations ending the AngloIrish War. It threatened the political composition and even the existence of the Northern Ireland because it challenged the six-county boundary within which unionists could expect

\footnotetext{
33 With this act they superseded the previous local name convention for the valley, the "Happy Valley". Possibly they considered the rhetorical difficulties of promoting a public project to flood the "Happy Valley." The valley was uninhabited. Loudan (1940) In Search of Water, p. 86.

34 Carson (1981) The Dam Builders, p. 4.
} 
majoritarian control of government and economic viability. Very early the reservoir site became enrolled in the highly politicized boundary dispute.

The Irish question had been particularly difficult for British politicians because it divided the post-war coalition (between the Liberals and the Conservatives) put together by Lloyd-George (leader of the Liberal party) because conservatives supported the Ulster unionist population, whereas liberals were less willing to do so. Lloyd-George sought to hold his coalition together long enough to get past the Irish question. To move negotiations past impasse he suggested a boundary commission which the Irish were given intimations might severely delimit the northern six county government boundary and possibly encourage them to become part of the southern Irish state for reasons of truncated economic viability. ${ }^{35}$ For this clause Lloyd-George was able to limit Irish autonomy to dominion status (allegiance to the crown and some financial ties) within the British empire and push the difficulty of Irish disagreement into the future. When the question resurfaced Lloyd-George's coalition collapsed and there was a succession of two conservative governments and then the first Labour government. ${ }^{36}$

By 1924, the Irish were demanding this boundary commission while Ulster unionists refused to appoint their member to the three-person commission. The Ulster unionists hoped to ignore or delay the boundary issue until a new English election once again brought about a more supportive conservative government. Inheriting the Irish question, the new Prime Minister, Labour leader Ramsey MacDonald, intended to legislate that the British government would nominate a commissioner on behalf of Ulster. The Boundary Bill, on the parliamentary calendar for late September (1924), was a potential crisis for the northern government. According to the treaty the Commission would determine the boundary "in accordance with the wishes of the inhabitants, so far as may be compatible with economic and geographic conditions". ${ }^{37}$ Significant regions and municipalities were primarily Catholic including Newry and the Mourne Mountains where was located the catchment area for the expensive reservoir now being built. Might Ulster unionists contemplate Belfast's water supply held (or withheld) by a foreign power that wished to coerce them into a united Ireland or demand changes in electoral or housing policies (such as those which discriminated against Catholics)?

\footnotetext{
35 A number of other considerations such as not privileging Ulster economically, created a sense of balance in the agreement, as if the future could go either way. It has been suggested that British Prime Minister Lloyd-George allowed both parties to understand the agreement's intentions differently. I rely primarily on Kevin Mathews account of negotiations. Kieran Rankin and Paul Murray describe partition within its earlier pre-history of political and social factors. Mathews (2004) Fatal Influence: The Impact of Ireland on British Politics, 1920-1925 Dublin: University College Dublin Press; Rankin (2007) "Deducing rationales and political tactics in the partitioning of Ireland, 1912-1925" Political Geography 26:8:909-933; Murray (2004) "Partition and the Irish Boundary Commission: A Northern Nationalist Perspective" Clogher Record 18(2) 181-217; Murray (2011) The Irish Boundary Commission and its Origins, 1886-1925 Dublin: University College Dublin Press.

36 When Lloyd-George's coalition fell apart shortly after, the conservatives led by Prime Minister Bonar Law (an Ulster sympathizer) provided additional economic support, including funding to arm sectarian protestants as a special constabulary, thus strengthening the Ulster unionists and changing any previous balance. By the end of this period the polarity of British party politics had transformed from liberal-conservative to (throughout the rest of the twentieth century) labour-conservative. The Liberal Party never returned to power. Mathews (2004) Fatal Influence.

37 Neville et al. (1992) "The Northern Ireland-Irish Republic Boundary" Espace Populations Sociétés 1992-2:215-226; Hopkinson (1990). The Craig-Collins Pacts of 1922: Two Attempted Reforms of the Northern Ireland Government. Irish Historical Studies, 27(106), 145-158.
} 
Early in September of 1924 the Water Commissioners brought key figures in the British parliament up into the Mourne Mountains to the Silent Valley to tour the works, lobbying them in what they labelled as a "non-political" act: that any public body charged with supplying water to its citizenry would comment against the forfeiture of control over its largest water source. ${ }^{38}$ In this they had worked carefully with Northern Ireland's Prime Minister Sir James Craig and his newly formed government, who desired to undermine and dissolve the Boundary Commission (Fig. 2).

The secretary of the Water Commissioners warned,

...if by any unhappy circumstance the supply from these mountains could be rendered unavailable, or in any way interfered with, there would follow consequences... disastrous to the manufacturing and shipping industries and... the community, the extent of which it is impossible to overestimate.

The Water Authority of Belfast is a strictly non-political body, and its Board of Commissioners recognize that fact and that their constituents comprise all classes of political thought. ${ }^{39}$

The Water Commissioners and their impressive mountain scenery were being presented as the non-political centre of a fairly political sandwich. That evening the M.P.s were to be entertained at the Ulster Reform club where Craig would speak with them. The nonpoliticalness of the Silent Valley Reservoir was politically convenient. It gave a rationale of nonpartisan water necessity to the British legislators, some of whom were perhaps already inclined to support the Unionist cause.

Although the Conservatives could not stop the bill, they put it through Parliament with a non-binding addendum suggesting territorial change should be limited. ${ }^{40}$ During the summer of 1925, when the new Boundary Commission was taking evidence and preparing its report, excavation began at the Silent Valley. It wasn't long before difficulties arose because of fluid subsoil. After timber-lined sumps had subsided steel cylinders 9' in diameter were driven into the line of excavation for the cut-off trench. The material which had both fluid and solid properties was ambiguous enough that men excavating within the cylinders had to be harnessed with a rope so that they could be pulled out should the inflowing ambiguity suddenly prove dangerous. ${ }^{41}$ The responsibility for these difficulties became a topic of disagreement between the engineer for the Water Commissioners and the contractor. At the same time, the boundary issue hung over the Ulster unionists of Northern Ireland. In October James Craig was trying to be certain they had secured Newry, ${ }^{42}$ while in the Silent Valley excavation had halted as the two engineers exchanged legal correspondence on whether or not changes in design were necessary. ${ }^{43}$ By the end of October Craig had intimations that Newry would not be lost. ${ }^{44}$ Therefore the Silent Valley (which was east of Newry) would also remain. The expected territorial transfer would probably be insubstantial.

\footnotetext{
38 Sep 131924 News-letter in 'Newspaper Clippings', unpaginated, located in WAT/1/3F/3/5 and WAT/1/3F/3/6 Water Commissioners' Papers, PRONI, hereafter cited as 'date, newspaper.' See 'Archival sources' for referencing convention.

39 Sep 131924 News-letter.

40 Mathews, Fatal Influence (2011).

41 "Brief for S. Pearson \& Son (Contracting Department) Ltd." Pearson Collection, Box 7 section 4a p. 5 hereafter cited as "Brief".

42 Mathews, Fatal Influence (2011).

43 "Brief" pp. 6-7.

44 Mathews, Fatal Influence (2011).
} 
Ultimately, the Boundary Commission's report was leaked and then suppressed. A story in the Morning Post on November 7th outlined the extent of the boundary and heralded the success of the award for Ulster, creating an immediate political crisis for the government of Ireland. The Irish appointee to the Boundary Commission announced his belated resignation. Five days later, the contractors for the work in the Silent Valley notified the Water Commissioners that they were invoking the dispute resolution clause of the contract. ${ }^{45}$ Perhaps the contractors now felt there was slightly more room within which to resolve the problem, but the dispute was still not made public.

The leak and subsequent suppression of the Boundary Commission report had the effect of solidifying the northern state. ${ }^{46}$ Like ships passing each other in the night, the boundary crisis (very public) and the Silent Valley crisis (concealed), seemed to slide past each other as if without encounter.

Over the summer and autumn of 1926, the difficulties in the Silent Valley were further explored in 'without bias' negotiations, but no resolution was forthcoming. Eventually, it became public knowledge that the contractor and Water Commissioners were in legal dispute with a date set in early December for arbitration hearings. Like rain-heavy clouds, journalists and interested parties began to convene.

\section{The setting of the legal dispute}

The sources suggest that the specific room where the arbitration was held was full of important people. On the walls that day were an array of maps and diagrams of the engineering work at the Silent Valley, ready to illustrate the technical matters to be discussed. Mr. W. I. Quinn, secretary for the Water Commissioners, had made the arrangements. A function room in the Slieve Donard Hotel in Newcastle, County Down, had been reserved. The counsel representing Pearson \& Sons was Sir Lynden Macassey, K.C. and Jim Whitaker, K.C. instructed by Horace Davey in London and Mr. Charley McDowell in Belfast. Horace Davey was the regular legal counsel for Pearsons. He had prepared most of their cases, including similar legal contests that Pearsons had been involved in, such as the Littleton reservoir dispute in 1922 with the London Metropolitan Board (discussed below). The other solicitors had been retained specifically for this dispute. Sir Lyndon Macassey was an interesting choice for counsel and perhaps not accidental. Sir Lynden Macassey would not have been unfamiliar with the history of this project. His father Luke Macassey had been the chief engineer for the Water Commissioners until 1908, before their present engineer Frederick W. McCullough, who redesigned the original scheme and set about finding contractors. But now, less than three weeks before the arbitration, McCullough had suffered a seizure while driving. At this crucial juncture, when the Water Commissioners faced litigation on complex technical and legal issues of contract and design, when they most needed their engineer, he was at his home stricken with pleurisy. By April he would

\footnotetext{
45 "Brief" p. 7.

46 Bew et al. (1979) p. 44. Many accounts of the boundary dispute have neglected the role of water while emphasizing the economic necessity of maintaining the linen industry. James Craig sought to intervene to additionally limit his government's financial responsibilities to Britain. As part of these negotiations Ireland, Britain and Northern Ireland agreed to shelve the Boundary Commission report and some of the other financial clauses in the 1921 treaty leaving the existing boundary intact. These negotiations were completed early December (Mathews, 2011).
} 


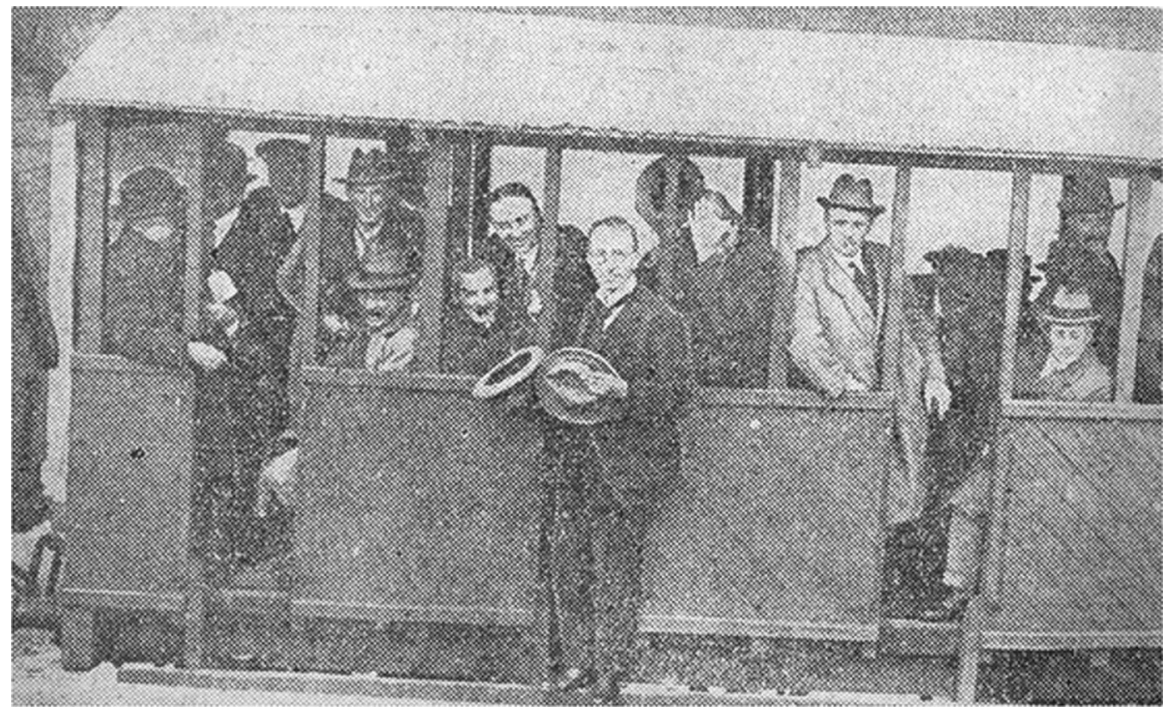

Fig. 2 British politicians lobbied by Water Commissioners, shown here departing for the Silent Valley with the Attorney General "on footboard acting as checker." Craig's government coordinated with the Water Commissioners to demonstrate the planned reservoir location to British parliamentarians thought to be potentially sympathetic to the unionist cause. Here travel is by the full English gauge railway $4^{\prime} 81 / 2$ " built in 1923 specifically to deliver construction materials from Annalong harbour up to the Silent Valley. Source: Sep 121924 Telegraph

be dead. ${ }^{47}$ Despite being without their lead engineer, the Belfast City and District Water Commissioners were well represented in legal authority by none less than the AttorneyGeneral for Northern Ireland (the Right Honourable A. B. Babbington, K.C., M.P.), Mr. E. S. Murphy, K.C., and Mr. R. D. Megaw, K.C., instructed by Mr. R. E. McLean in Belfast. Mr. McLean was the regular solicitor for the Water Commissioners retained for all their legal disputes.

The Arbitrator as specified in the contract clause on dispute resolution was Mr. William J. E. Binnie, M.Inst. C.E. of the firm Sir Alexander Binnie, Son, and Deacon, 30, Buckingham Gate, Westminster, S.W. Sir Ernest Moir, described in the Daily Mail as the engineer-in-chief to Messrs. Pearson, was at hand and prepared to do much of the presentation himself. ${ }^{48}$ Having worked for Pearsons all over the world, Moir brought considerable experience. He was a potential conduit for lessons learned in other geographies, including his experience with politically contentious excavations under increased air pressure. ${ }^{49}$ All these important persons and others associated with the case were present in the function room of the Slieve Donard hotel that winter morning in Newcastle when Sir Lynden Macassey rose and asked Mr. William Binnie "Are you ready, sir?" With that statement the long-awaited arbitration began. Maccassey's argument would be like the concentric spherical layers of an onion, each opening up to the next within itself. He would emphasize common interests, then articulate the legal argument delineating responsibility for errors

\footnotetext{
47 Mar 281927 Telegraph.

48 Dec 161926 Daily Mail.

49 Moir designed the Hudson River tunnelling shield (discussed below under 'Precedents').
} 
in design, describe the design argument related to subsoil removal by a particular method, and then provide the history of sub-soil excavation to ask whether the nature of the material would lend to excavation by the design-prescribed method. From guidance by the law he would pass over the decision-making power to the expertise of science.

\section{Emphasizing common interests}

From the start of the arbitration it was clear that Sir Lynden Macassey presenting the case on behalf of Messrs. Pearson was to be very diplomatic. The legal dispute was characterised as a common difficulty that both the Water Commissioners and Pearsons shared, that perhaps the Arbitrator could resolve. For a year the sub-soil problem had been debated with increasing difficulties. When other forms of resolution failed the contractors turned to the legal frameworks and filed a grievance to be resolved by arbitration as per the dispute resolution clause in the Contract. The Water Commissioners had been led in this conflict by their chief engineer, McCullough, now absent. So Pearsons' legal team may not have been entirely clear to how the Commissioners would now react. The situation had the potential to go badly wrong.

Having established a basic description of the project, Sir Lynden began to describe in more detail the circumstances which had brought all parties to this arbitration. Amongst the many diagrams arrayed upon the wall, he drew attention to one for the arbitrator to see which could summarize the difficult situation.

To indicate the character of the difficulty, there confronts you, sir, on that wall is a cartoon and it shows the longitudinal section along the centre line of the embankment of the Reservoir. ${ }^{50}$

This diagram (Fig. 3) showed the cross section of the trench. First, the expected depth of bedrock given by the Water Commissioners engineer was illustrated by a line across the trench. The additional depths estimated by recent borings and metal bars thrust into the earth were also indicated on the diagram. With these, an estimated actual line of bedrock could be shown to be very probably at a considerably greater depth than predicted by the Engineer. ${ }^{51}$

With this drastic summary of the situation Macassey was then able to hint at the possibility of a negotiated resolution, something that the contractors would like to bring to the dispute.

I may say this, that of course one recognises that the object of the Belfast Water Commissioners is to obtain a reservoir. That is what they desire to obtain. I may equally ask them to recognise this, that the object of Messrs. Pearsons \& Son is to build a reservoir for them, if that reservoir can be built. That is their object and therefore, sir, I think I may say that there is not much discord of view between the two parties, that is to say, between the Water Commissioners who desire a reservoir and Messrs. Pearson who desire to build them a reservoir, but what I think I shall satisfy

\footnotetext{
50 WAT/1/3E/1/8, p. 4a-5a.

51 The Silent Valley Reservoir was to be a million-ton gravity dam in which the weight of earth material, sealed with tramped puddle clay, would sit upon a concrete cut-off trench grooved into bedrock. The ability to locate and excavate down into bedrock was crucial for the viability of the dam.
} 
you is this, that neither of the aspirations of the two parties can possibly be satisfied under the terms of the existing contract, as we say. ${ }^{52}$

The strategy of Pearsons' legal team was not to place blame on the other party but to displace blame entirely. They would very much like to line up the subject position interests of both parties. Such a strategy must have developed and come to seem plausible in the face of few other options. The Contractors did not wish to shoulder the blame and be made financially responsible for the difficulties. But neither did they wish to make enemies of or undermine the Water Commissioners on whom they depended as sponsors of the project. Undermining the Water Commissioners in a public trial might result in the termination of the water scheme. Ratepayers and other political opposition to the Water Commissioners had to be considered. These other parties could destabilize the project if given opportunity within this controversy. Also, as a business S. Pearson \& Son's reputation for getting work done was important. Their reputation would enable them to pursue other business elsewhere. A difficult and vindictive legal battle resulting in no reservoir being constructed would not reflect well upon Pearsons. Macassey enacted the situation thus,

There is this very unfortunate state of circumstances. Rock is not found at anywhere near the depth at which either party contemplated it would exist. Neither party is responsible for this unfortunate happening, and I think I may lay that responsibility on Providence, but there it is. It raises a condition of things which calls for very careful and anxious consideration by both parties. ${ }^{53}$

Here Macassey names "Providence" as the location to which blame could been displaced. "Providence" and "Nature" served as similar rhetorical tropes to displace politically damaging discussions of blame away from the two main parties involved in the reservoir construction, the Water Commissioners and the contractors. Ratepayers had opposed the expensive project and nationalists saw the Water Commissioners' role in the boundary debate as partisan. Intermittent political violence (although now less) was still occurring in Belfast. Under these circumstances "Providence" was an important rhetorical displacement. Material in the archival records does not provide an explanation for the choice of this word. Nor do we have the specific reasoning for the strategy Sir Lynden quite evidently pursues, but we can see he is a skillful actor. We must assume he can see the situation he is placed within as representative for the contractor and seeks to navigate through this difficult social field of forces and valences associated with different interest groups, each with different levels of authority or ability to sabotage the project. ${ }^{54}$ From this basic explanation of the circumstances and suggestive remarks about negotiation Sir Lynden switched to discussing the legal case for responsibility from the Contract.

\footnotetext{
52 WAT/1/3E/1/8, p. 6 a.

53 WAT/1/3E/1/8, pp. 6a-7a.

54 Social actors make choices within the context of how they variously perceive their situation including influences or valences emanating from conditional circumstances. Martin (2011) The Explanation of Social Action New York: Oxford University Press (especially Chap. 6-8). The role of skilled social actors is important in maintenance or transformation of what we would normally expect to be stable social fields. Fligstein and McAdam (2012) A Theory of Fields Oxford, New York: Oxford University Press.
} 


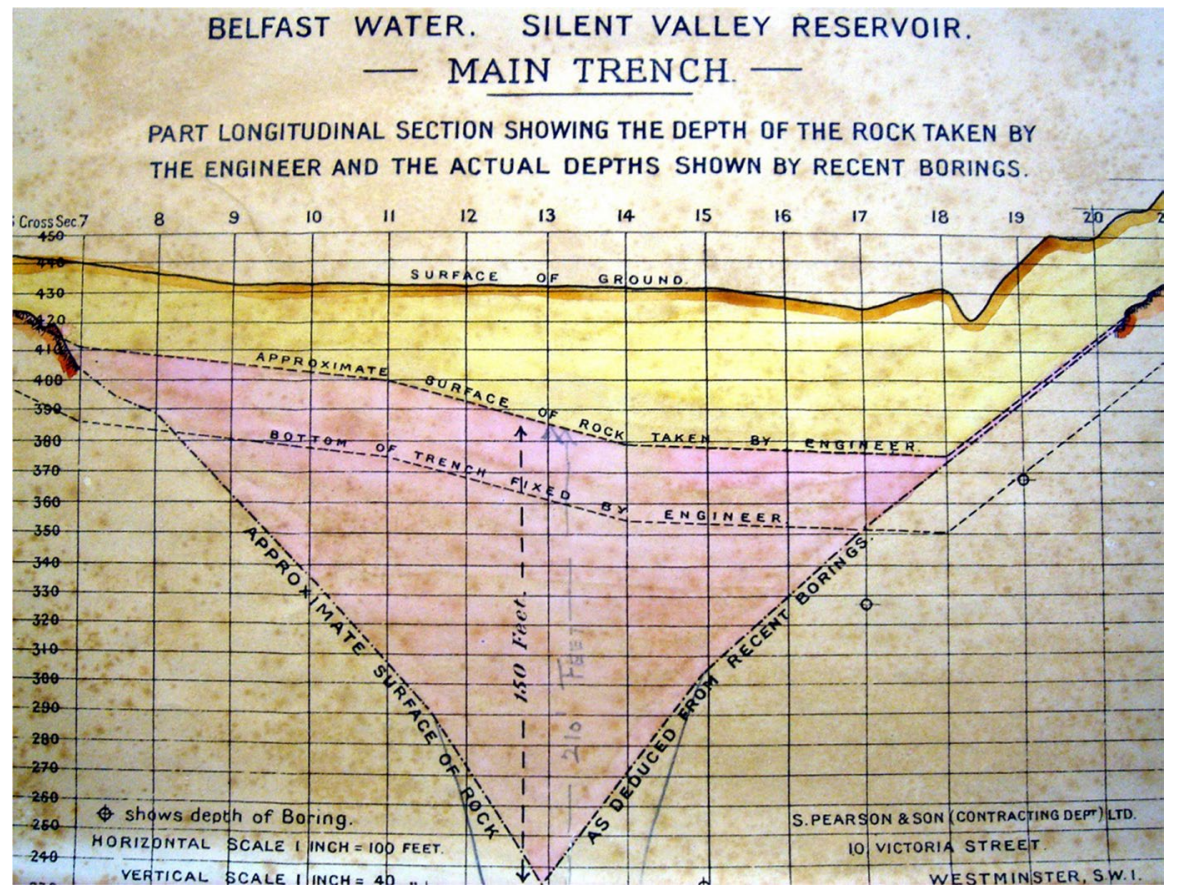

Fig. 3 Maccassey's ‘cartoon' of the depth. Source: Pearson Collection

\section{The legal argument}

Legal frameworks might be thought of as a matter of sovereignty enacted at the procedural level. This means that they resolve conflicts between several alternative (and often assumed to be conflicting) actions, arrangements, or options so as to bring about (usually by legal imposition) a common course of action on all parties. While the general actions of legal procedures are an expression of sovereignty (procedural sovereignty), the legal system as a whole is connected to the sovereignty of the state. The legal system is designed to uphold the day to day economic and social order which the state both supervises and is upheld by. State sovereignty establishes and authorizes a legal system. ${ }^{55}$ In a case of arbitration using a legal framework we would thus expect there to be (in addition to the legal framework itself being described as sovereignty at a procedural level) an indirect connection to state sovereignty in that the rule of law is ultimately guaranteed by the state.

However, in this particular arbitration the interests of 'state-level' sovereignty can be seen more directly. The Attorney General's presence as the legal spokesperson for the Water Commissioners but also the highest legal authority in the Northern Ireland, the state's lawyer, is indicative of the attention which this matter of water is receiving from the governing agents of sovereignty. In very recent memory the Silent Valley had been highly politicized when the Commissioners had worked with Prime Minister Craig to include

\footnotetext{
55 Jessop (1990) "Recent Theories of Law, the State, and Juridico-Political Ideology", pp. 48-78, in Bob Jessop (1990) State Theory: Putting the Capitalist State in its Place UK: Polity Press.
} 
Belfast's water supply in his boundary argument. Now his government was once again paying attention to water.

Sir Lynden would now explain the contract and demonstrate its relevance to his argument. While the general strategy of Pearsons was to displace blame and promote negotiation, the specific legal strategy with regard to the Contract is more directly an attempt to gain the upper hand during negotiations in order to force a settlement beneficial to Pearsons. Pearsons' legal team intended to demonstrate authority for their position from the Contract and thus mark negotiation as the only option for the Water Commissioners. This very direct legal conflict was smoothly covered over with the diplomatic rhetoric of common interests that Sir Lynden has presented in his initial description of the situation. 'Providence' provided an acceptable blame regime, making invisible political critics who might provide less celestial attributions of fault. His overall strategy would be to demonstrate that legally the Commissioners were responsible for failure of design, that the design required a particular method (wooden trench) which was unsuitable because of the nature of the subsoil (fluid). The arbitrator could then be asked to make a judgement on the nature of the material. Was it or was it not dissociable from its water within the scope of wooden trench design? But first he had to establish the legal argument. This he does in a very particular way. He uses the contract as a material object in itself. The history of technology has emphasized how documents, plans, and specifications are used in construction as an object, not simply for their information content, but as part of a performative capacity in expressing and "mediating social relations". 56

Sir Lynden's first task is to identify for the other members of the arbitration the contract. This he does by emphasizing its unusual condition. He is particularly keen to push aside the more simple representations of the signed agreement which might at first seem to contain the relevant information.

The contract is a document which consists partly of print and partly of manuscript amendments and alterations, and I think it will be necessary for you in following my argument to have before you a copy of the exact document which was signed so that you can see the deletions of the print which are made in manuscript and the additions to the print in manuscript which were inserted. I do not know whether you have a copy of the printed contract. It looks nice clean print.

THE ARBITRATOR-Mine is clean print.

SIR LYNDEN MACASSEY-That I do not think will be sufficient for you. [...]

May I hand you what I understand is a facsimile copy of the original and ask you to be good enough to use that until you have an opportunity of seeing the original. ${ }^{57}$

The contract and specification which was signed was the result of a long negotiation process. A version of the contract and specification had been printed in advance of the actual signing of the contract. In the last few days before the contract was signed considerable renegotiations happened. These renegotiations were represented with sheets of typing paper insertions and red lines crossing out those sections which were to be removed. The contract and amended specification was then signed in this state of production, rather than waiting for a printed version which removed the history of the negotiations. The contractors' copy of the original similarly indicated the history of the negotiation. After the

\footnotetext{
56 Dobraszczyk (2008) "Image and Audience: Contractual Representation and London's Main Drainage System”, Technology and Culture 49:3, p. 569.

57 WAT/1/3E/1/8, p. b1.
} 
signing occurred, printed versions of the contract were made by the Water Commissioners. These did not show the editing marks created during negotiation but rather merely the end results. Here the material structure of the contract, specification, and associated documents plays an active role in determining what will ultimately become (or not become) a reservoir. As we will see below, the greater level of detail in the edit marked original (and the replica of the edit marked original), will allow the contractors' legal team to assert particular connections to the past. ${ }^{58}$

Having successfully asserted to the other participants in the arbitration that the document indicating the contract will be the original replica, Sir Lynden then began to outline the structure of the legal documents. ${ }^{59}$ The contract included several attached documents which set out a covenant of payment in return for service. The 'Form of Tender' was signed and sealed by the agent of the contractor (and then additionally signed and sealed by the agent of the Water Commissioners). Attached to the form of tender was the 'Specification' including a schedule of quantities, written by the Water Commissioners' engineer. After generally outlining the remit of the contract, the Specification detailed the design work that was required of the contractor. The schedule of quantities listed specific items of labour or materials to be provided and gives the prices for which the contractor had agreed to provide such. The drawings were also legally included within the contract. During the signing of the contract each of twenty odd engineering drawings were examined and initialled.

Sir Lynden especially emphasized that it is the amended specification which has been agreed. The implications of this he explained thus:

So when one looks at the amended Specification ... you will observe that the last clause in the amended Specification is 356 and that it is struck out. Would you be good enough to look at that because these deletions, of course, which exist in the signed document, are just as much part of the signed document as the print. ${ }^{60}$

The contract and form of tender actually signed required the execution of the Drawings and that which is "in the amended specification." Sir Lynden repeated this phrase to emphasize that the relevant document to be considered is the original replica with deletions and insertions (Figs. 4 and 5). It was a particular deletion at the end of the amended specification which Sir Lynden wished to emphasize. The deletion would not have been present in the printed representation of the Contract which the Water Commissioners' legal team had provided for the arbitration process. ${ }^{61}$

Sir Lyndon read aloud and then commented on the clause that was struck from the contract, clause 356 , the warranty clause:

"The Contractor further agrees and binds himself to provide and execute all matters and things whatsoever, in addition to those shewn on the Drawings and herein-before

\footnotetext{
58 According to the record of the arbitration the original was in fact never produced during the proceedings but rather the original replica held by the Contractors was used in the Slieve Donard Hotel for the Arbitrator to follow the argument. To the Arbitrator the distinction between the printed representation of the contract and the edit marked original document is almost certainly novel information. For the Attorney General of Northern Ireland, the legal implication of asserting this distinction may or may not have been immediately recognized but like the Arbitrator he also indicated a ready willingness to use the printed representation.

59 WAT/1/3E/1/8, pp. b2-b3.

60 WAT/1/3E/1/8, pp. b3-b4.

61 In sociolegal studies of contract law a recent approach is to look directly at the contract as a material object with effects. Suchman (2003) “The Contract as Social Artifact” Law \&Society Review 37/1:91-142.
} 
specified, as may be necessary to make the intended Reservoir... without any payment beyond the Contract sum, and... notwithstanding any defect in the design of the Works... he shall complete and maintain and hand over the said intended Reservoir and other Works complete in every respect..."

If that clause stood it was an assumption by the Contractor of full reliability and responsibility for executing the Reservoir, notwithstanding any defect in the design of the Works. That was struck out and there are certain very significant insertions... if I may, just point you out what the insertions were. ${ }^{62}$

Sir Lynden went on to explain the organisation of the contract giving special attention to these insertions. These insertions exist he claimed in clause 5 regarding the extent of the Contract and clause 7 regarding Drawings. ${ }^{63}$ It is worth noting that his narrative imposes a chronological logic to the negotiation of the contract. By beginning at page 86 of the Specification, giving significance to a deletion, and then returning to page 2, clause 5 and page 3, clause 7 to claim that the insertions at these locations are in response to the deletion Sir Lynden presented the significance of the contract in a particular way. He interpreted it diachronically. With the greater level of detail in the edit marked original replica Sir Lynden could tell a historical narrative about the meaning of the contract as it emerged from the original negotiation process. Some of the influences upon the original negotiation process (discussed below) were now becoming influences upon the arbitration. As we will see, these influences were geographically diverse.

Clause 5 specified the liability of the contractor for damages caused by executing the plans incorrectly but, significantly, not such damages as caused by defects in plans which were executed correctly. Sir Lynden: "So you see that, so far as any defect in the design is concerned, there is a very material difference in the contract as drafted and the contract as signed." ${ }^{64}$ Clause 356 as drafted had required of the contractor responsibility for defects in the plans. With that clause now struck, Sir Lynden claimed that clause 5, saying something quite different, was instead the relevant clause for the issue of liability.

Clause 7 referred to the drawings, which were to be accepted by the contractor "as sufficient in all respects to indicate the nature extent and particulars of the intended Work... the Contractor binds himself and agrees to make no claim whatsoever against the Commissioners," and here the words "for any payment" had been cut out. Likewise "unsuitable or insufficient design" had been struck from the list of reasons that the Contractor agreed not to make a claim. ${ }^{65}$

\footnotetext{
62 WAT/1/3E/1/8, pp. b4-b5.

63 I have been able to locate two versions of the negotiated contract, one at the Public Record Office of Northern Ireland (PRONI WAT/1/3J/3) and one in the Pearson Archives attached to the Science Museum Library. The PRONI version does not include these insertions so it is probable that this was not a document from the final stages of contract signing but is instead an earlier version exchanged between Pearsons and the Commissioners during the process of negotiation. This Specification Wat/1/3J/3 has a hand-written note on it (signed WQ) which says "Secretarys copy. amendments in red made by Messrs. Pearson + Son Ltd. and received with their letter of 21 May 1922WQ note-page 9 out of place + follows page 12." Sic. In the Public Record Office document page 9 and 12 are not out of order. This suggests the document has been rebound. The version of the contract which exists in Pearson Archive is a facsimile of the original signed document. Most probably it is the actual original replica that was handed to Mr. Binnie and used during the arbitration.

64 WAT/1/3E/1/8, p. B6.

$65 \mathrm{WAT} / 1 / 3 \mathrm{E} / 1 / 8$, pp. B6-B7.
} 


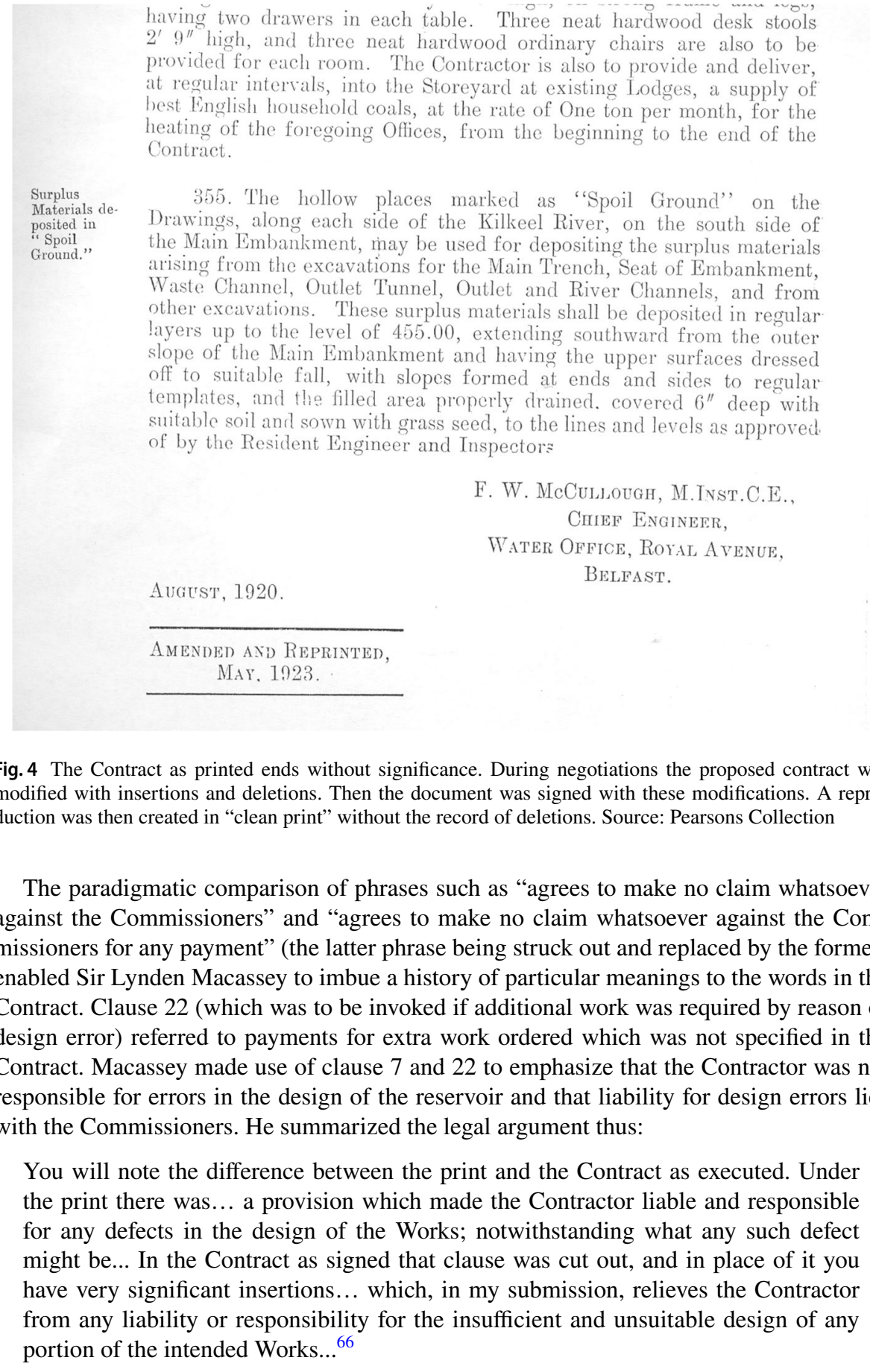

having two drawers in each table. Three neat hardwood desk stools $2^{\prime} 9^{\prime \prime}$ high, and three neat hardwood ordinary chairs are also to be provided for each room. The Contractor is also to provide and deliver, at regular intervals, into the Storeyard at existing Lodges, a supply of hest English household coals, at the rate of One ton per month, for the heating of the foregoing Offices, from the beginning to the end of the Contract.

Materials

posited in

"Spoil

the south side of the Main Embankment, may be used for depositing the surplus materials arising from the excavations for the Main Trench, Seat of Embankment, Waste Channel, Outlet Tunnel, Outlet and River Channels, and from other excavations. These surplus materials shall be deposited in regular layers up to the level of 455.00 , extending southward from the outer slope of the Main Embankment and having the upper surfaces dressed off to suitable fall, with slopes formed at ends and sides to regular templates, and the filled area properly strained. covered 6 " deep with suitable soil and sown with grass seed, to the lines and levels as approvei of by the Resident Engineer and Inspector:

\section{F. W. McCullough, M.Inst.C.E., \\ Ciref Engineer, BELFAST.}

\begin{abstract}
Fig. 4 The Contract as printed ends without significance. During negotiations the proposed contract was modified with insertions and deletions. Then the document was signed with these modifications. A reproduction was then created in "clean print" without the record of deletions. Source: Pearsons Collection
\end{abstract}

The paradigmatic comparison of phrases such as "agrees to make no claim whatsoever against the Commissioners" and "agrees to make no claim whatsoever against the Commissioners for any payment" (the latter phrase being struck out and replaced by the former) enabled Sir Lynden Macassey to imbue a history of particular meanings to the words in the Contract. Clause 22 (which was to be invoked if additional work was required by reason of design error) referred to payments for extra work ordered which was not specified in the Contract. Macassey made use of clause 7 and 22 to emphasize that the Contractor was not responsible for errors in the design of the reservoir and that liability for design errors lies with the Commissioners. He summarized the legal argument thus:

You will note the difference between the print and the Contract as executed. Under the print there was... a provision which made the Contractor liable and responsible for any defects in the design of the Works; notwithstanding what any such defect might be... In the Contract as signed that clause was cut out, and in place of it you have very significant insertions... which, in my submission, relieves the Contractor from any liability or responsibility for the insufficient and unsuitable design of any portion of the intended Works... 


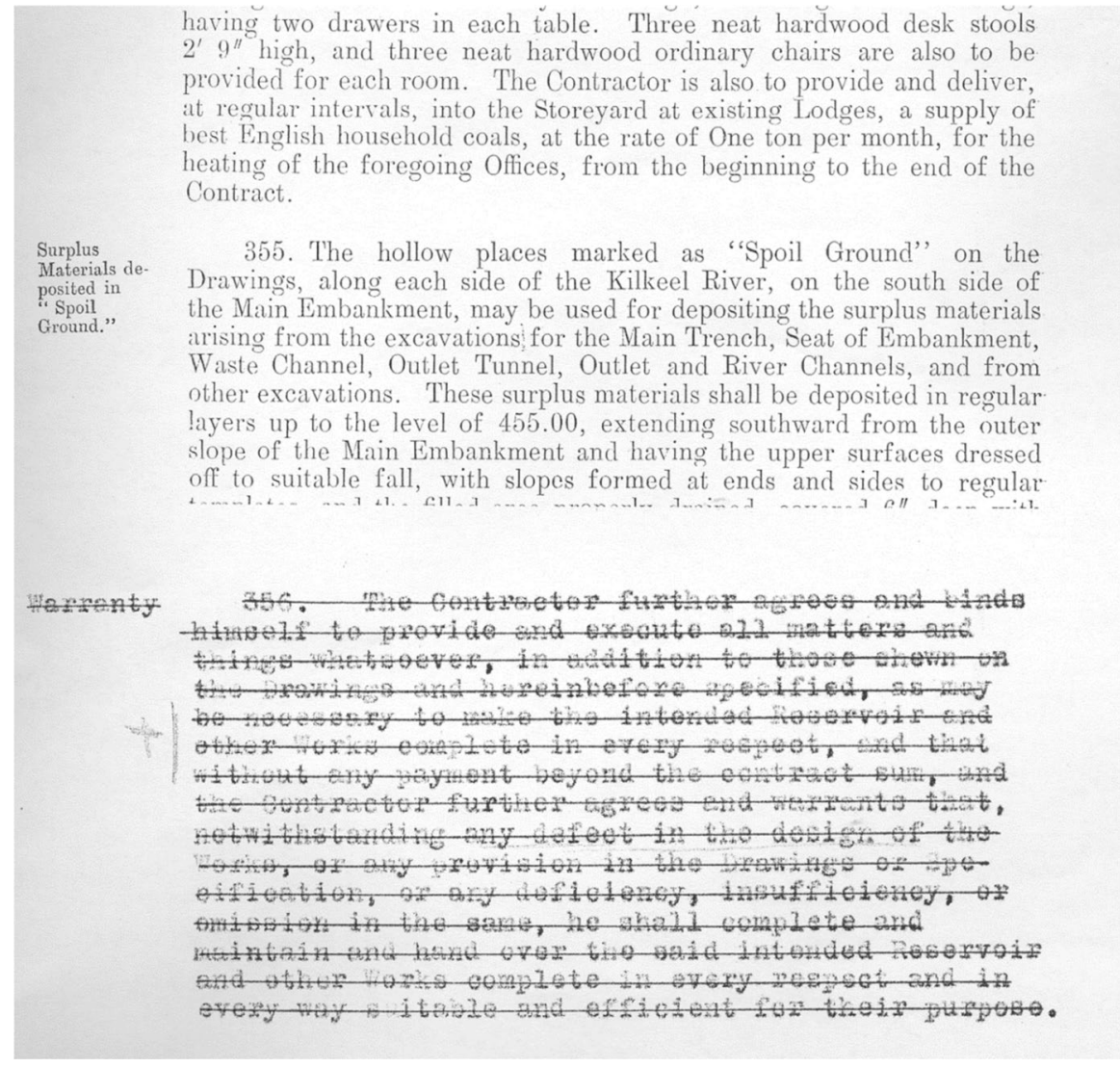

Fig. 5 The Contract as signed: Tracing paper insertions show what was removed. The 'exception' of this clause is included within the Contract, thus determining the legal interpretation. Source: Pearson Collection

This was the main portion of the argument presented by Macassey at the arbitration. If the legal Contract, as he claimed, held the Commissioners responsible for defects of design then Macassey must need also to establish that the design as provided by the Water Commissioners was unfit or unsuitable for its purpose. According to Macassey's presentation the important issue would now be whether or not the trench could be excavated as per the method originally stipulated in the Specification.

\section{Design and the boundaries of nature}

The initial point at which the design first seems inadequate was the suggestion that a timber-lined trench (as per Specification) would enable excavation. Clause 150 in the contract specified that the trench was to be securely timbered and that in the process of concreting no timbers could be left behind. Macassey claimed that this very specific method being dictated from within the contract was unusual. More frequently engineering contracts of this period simply specified the required results and let the contractors determine 
methods. ${ }^{67}$ Sir Lynden Macassey summarized the most important bit of his argument. The timber lined trench as the specified means of excavation was the salient error in the design.

Having established what the design required, he now had to demonstrate that the circumstances and the nature of the material made such a method inadequate for excavation. The arbitration had to, in the final instance, resolve a dispute about nature. Thus the procedural level of sovereignty (represented in the Arbitrator's power to decide) was being asked to make a judgement on the boundaries of nature. As is typical in dispute resolution clauses during this period, the arbitrator was a prominent engineer. Conflicting representations of nature, prepared in the form of charts, graphs, and diagrams, were to be shown to Mr. Binnie so that he might judge which were to be considered matters of fact and how these facts should be arranged. An important question for those involved in the arbitration was 'What is the nature of the sub-soil?' For example, is water intrinsic to the material or can the material be dewatered? If it couldn't then a timber-lined trench was inappropriate design for a fluid material. It was the arbitrator-as-engineer's expertise (i.e. scientific sovereignty) which was to be the basis for judgement.

Macassey began to describe the circumstances during excavation that led to the initial concerns. The nature of the material was invoked both in the way that it could be seen to relate unusually to water and in the presence of a groundwater level below which excavation was difficult.

The curious thing about this material is that ... when you proceed to pat it ...-I dare say scientists will differ as to the reason but will agree as to the fact-it proceeds to become a kind of jelly, ... the vibration seems to extend in cylindrical rings for a considerable distance ${ }^{68}$

Then followed an explanation of the investigation of the material, and attempts to drain the sub-soil by building a sump. Around about the depth of 416 feet ordnance datum ${ }^{69}$ the water level was always encountered and the timber runners to uphold the stability of the sump excavation suffered subsidence.

when you get down to that depth the water proceeds, and as the material cannot part with its water without accompanying it you get not merely the water, but a flow of mixture consisting both of water and material ${ }^{70}$

The relationship of this difficult to excavate semi-fluid material to the possibility that bedrock was also considerably lower than expected was also given. The excavation of the trench from the high sides of the valley had been much easier until the rock suddenly disappeared steeply into the earth.

Macassey concluded by drawing attention to the nature of the sub-soil, which both predicates unforeseen difficulties and founds his argument. The disagreement about the nature of the sub-soil (for example, is water intrinsic to the material) were at one level a classic subject/object boundary disagreement. Knowledge of the object (including the boundaries which define the object) will be constructed within the context of a purpose to which the knowledge will be put. That purpose is based on the boundaries of the subject (who the

\footnotetext{
${ }^{67}$ In this case expertise has been retained by the authors of the contract rather than relinquished to contractors. Presumably this was done to demand a meticulous quality to the work.

68 WAT/1/3E/1/8, p. 4D.

69 Ordinance Datum is a measure of altitude. 432 OD was the surface level of trench excavations.

70 WAT/1/3E/1/8, pp. 7D-8D.
} 
subject is and what the subject can do) which acts upon the object (both in constructing knowledge about the object and utilizing that knowledge through further actions on the object).

At least one part of the difficulty in ascertaining the material was that the Water Commissioners and the contractors had approached it with different purposes in mind. Their subject positions had been split because of concerns about who will bear the burden of additional costs (and also carry the risk of failure should the reservoir construction fail). Thus instead of investigating with a common purpose each sought to demonstrate the properties of the material which most supported their own best position in relation to the contract. For example, the Water Commissioners felt it was important to determine if the difficulty in de-watering the line of the trench was because the contractors had not sufficiently diverted the Kilkeel River from the works and thus the groundwater level was continually being replenished. ${ }^{71}$ That would not have been an error in design. During the year leading up to the Arbitration a great deal of discussion, gradually hardening into debate and then legal conflict, occurred about the nature of the problem, such that the room was now filled with charts, graphs and diagrams full of evidence prepared to assemble and support one arrangement of facts against another. Until the dispute between them was negotiated they would approach the question of the nature of the material from different subject positions.

At this point the case for the Contractor had been stated quite strongly and the session adjourned for lunch. The participants all had much to consider as they went for their meal. By placing the nature of the material at the focal point in the summary of his presentation Macassey makes the fluid nature of the sub-soil the foundation of his argument. From nature came the fluid properties of the sub-soil, from which arose unforeseen difficulties. The design given in the specification was inadequate to deal with these difficulties and the legal arrangements of the contract made errors of design the responsibility of the Water Commissioners. Perhaps, suggested Macassey very quietly inside the minds of the Water Commissioners and the Attorney General, perhaps it was time to negotiate.

\section{From arbitration to negotiation}

The informality of lunch allowed conversations to happen which were not as easily pursued in the formal legal setting of the arbitration room. When the session resumed after lunch the Arbitrator intervened to ask if some of the morning's argument was contested by the Commissioners. The Attorney-General rose to answer this. While gracefully noting minor quibbles, he said that substantially there was not disagreement on these points and that during lunch he had had the opportunity to discuss with Sir Lynden.

...it would be very much better if there were no break as between Messrs. Pearson and the Water Commissioners, and the Water Commissioners themselves recognise that... if we could have a discussion... having regard to the way in which Sir Lynden Macassey has stated the case for Messrs. Pearson, and the attitude they have taken up... we might be able to get rid of the difficulties... ${ }^{72}$

\footnotetext{
71 This argument did occur in the year leading up to arbitration and Pearsons had kept careful water temperature records between river and groundwater temperature to disprove this thesis. Graphical representation was brought to the arbitration, but it did not become necessary to produce it. Pearson Archive, Box 7. 72 WAT/1/3E/1/8, p. 4F.
} 
The arbitration was suspended until the following morning at 10 a.m. so that the two parties might negotiate a solution themselves outside of the legal hearing. By achieving a strong position within the procedural level of sovereignty, Sir Lynden was able to push for negotiation. Successful negotiation would help unite subject positions of the Water Commissioners and the contractors, thus enabling knowledge (the arrangement of facts for a particular purpose) to be constructed in the context of common purpose. The nature of the sub-soil could be investigated without diverging intentions. This common subject position at the level of questions of nature is emulated by the construction of commonality at the level of questions of sovereignty. In order to make space for the Water Commissioners and the contractors to have a common purpose (building a reservoir) Sir Lynden picked 'Providence' as the reason for difficulties. In this way blame would be drawn away from the Water Commissioners and their political authority (connected to sovereignty) would not be challenged. The identity of the subject position is influenced by opposition to some other. Both the Water Commissioners and the contractors could unite in their opposition to those who would prefer them both to fail. In this case the other was said to be nature or Providence. ${ }^{73}$ However in actuality the blame which was being avoided came from opponents of the Mourne Extension Scheme. Thus implicitly they were another 'other' which the Water Commissioners and the contractors both shared. Opponents of the Water Commissioners such as the well-to-do Rate Payers Association and those nationalists who followed the critical position of the Irish News were a source of common opposition which helped align the Commissioners and the contractors to a common subject position.

The following morning comments were brief. Progress was being made but the negotiations were not yet complete so the arbitration hearings were suspended one further day until Wednesday. The Belfast newspapers all covered the arbitration hearings. Even the Daily Mail from London sent a reporter to cover the case. However the press was not admitted into the proceedings. Instead, they were informed by a public statement made at 5.30 in the evening. The Daily Mail article described slightly more details for a London audience. Sir Ernest Moir was described as the engineer-in-chief to Messrs. Pearson. Their article for the second day ended poetically with a description of the weather which had blanketed the negotiations, "snow fell throughout the forenoon. Slieve Donard a white mantle."74 One letter in the Irish News on that day decried the policy of secrecy "in the Silent Valley." The text of the first morning of the arbitration was never released to the press.

The Wednesday morning December $15^{\text {th }}$, the participants of the arbitration reconvened with a negotiated solution and presented it to the Arbitrator, Mr. Binnie, who published his award a week later. Although the resolution of conflict clause in the contract laid out binding arbitration, the written award of the arbitrator was drawn from the results of the negotiations between the two parties to the dispute, Pearsons and the Water Commissioners. Mr. Binnie's award stated that Contract A was to be rescinded as of December 15th 1926. This was by mutual agreement. The Water Commissioners were to pay the Contractors all costs of construction accrued to date. In addition they would pay $10 \%$ extra for profit and

\footnotetext{
73 In theology, Providence is the sovereignty, superintendence, or agency of God over events in people's lives or at historical moments. Thus it comes to be something like a divine characterisation of chance, circumstance, or luck. Saying that Providence prevents gives a divine association to the confrontation with nature. Being defeated by God's nature is not a sign of weakness in the same way as being defeated by nature might be seen. For Sir Lynden, we might say that Providence is a characterisation of the state of facts or circumstances within the nature that god has created. On the chance/providence relation see also Martin (2011) The Explanation of Social Action New York: Oxford University Press, pp. 55-56.

74 Dec 151926 Daily Mail.
} 
$2 \frac{1}{2} \%$ extra towards the administrative costs of the Contractors' Londonoffice. Exploratory work would continue at the Silent Valleyfor an 18 month period in order to determine the feasibility of completing the reservoir. This exploratory work would be done by Pearsons. The remuneration was to be on the same cost plus percentage basis. In the absence of F.W. McCullough, the Water Commissioners engineer, the exploratory work would be directed by a Board of Engineers. Mr. Binnie, the arbitrator would act as Chairman of the Board of Engineers. Two other engineers were to be nominated, one by the Water Commissioners, and one by Pearsons. Respectively they nominated Mr. Edward Sandeman and Mr. Prescott Hill, M. Inst. C.E. Actions of the Board of Engineers would be by majority decision. Remuneration of these engineers was to be paid by the Commissioners, and negotiated accordingly, or failing agreement between the engineers and the Water Commissioners, to be negotiated by Sir Lynden Macassey and the Attorney General, the barristers for each party. At the end of the 18 month exploratory period, the Board of Engineers would make a recommendation regarding the feasibility of constructing a reservoir on the present line and, if necessary, they would prepare plans for doing so. If the Commissioners decided to go forward with the reservoir construction, the contractors, Pearsons, would be prepared to construct the reservoir on the same basis of remuneration under the direction of the Board of Engineers. The fees and costs of the hearing were to be borne by the contractor as specified in the arbitration clause of the original Contract A. "I have taxed or settled my fees and the costs of this Award at the sum of Four Hundred Pounds," 75 concluded William Binnie.

On the final day the press announced agreement, rock had not been found at 75 feet, nor at 150 feet, and presently at 218 feet of depth they were into running sand, claimed one newspaper. ${ }^{76}$ Remarks by Macassey that Pearsons were "surrendering a lucrative contract," made it into print. ${ }^{77}$ It was also noted that those negotiating were following a precedent set by the Metropolitan water authority. ${ }^{78}$ In the Irish News a correspondent claimed.

A gigantic blunder has been made... Belfast will sink into the Silent Valley financially bankrupted... hastening towards civic ruin... one of the great arguments against any interference with the boundary of the County Down used by the Government while the 'Border' humbug lived was the horrible danger of giving the Free State control over the invaluable Silent Valley. We may yet live to regret the Free State's failure to secure it ${ }^{79}$

The actual content of the negotiation was never made public. Much of it was probably never written down. Most of the outcome of that negotiation (certainly the legal arrangements) is apparent in the agreement published as the Arbitrator's Award a week later. All the negotiation of substance happened on the Monday and Tuesday (if not before) and the final day of the arbitration proceedings seems likely to have been choreographed. The conclusion to the arbitration gave both Water Commissioners and the contractors the appearance of having designed a well-made and mutually agreeable solution to a difficult problem. This would protect the project from potential critics in the city of Belfastwho might make the situation even more difficult if given any opportunity. Neither the Water

\footnotetext{
75 WAT/1/3E/3/10 "Award of the Arbitrator" December 24th, 1926.

76 Dec 161926 News-letter.

77 Dec 161926 News-letter.

78 See below: 'Precedent'.

79 Dec 161926 Irish News.
} 
Commissioners nor the contractors wanted it to look like the contractors had got the best of the Commissioners.

\section{The arbitration of nature}

In order to understand the relationship of sovereignty to a judgement at the level of fluid material, let us consider again the two things that Sir Lynden had to accomplish.

1. In terms of 'nature', the contractors hoped to find a solution to the excavation difficulties without being forced to pay for it out of their own pockets; whereas

2. In terms of 'political authority', the contractors were ambivalent about confronting the Attorney General of Northern Ireland or the Water Commissioners whom he represented.

The presence of the Attorney General indicated a sovereign interest in the outcome. The controversial and expensive project had opposition and was thus subject to possible cancellation in the event of prolonged dispute, a situation which neither the Water Commissioners nor the contractors desired. Pearsons depended on the authority of Water Commissioners for the construction contract. A victorious legal battle resulting in an un-built reservoir would not benefit the contractors. To avoid such a Pyrrhic victory, the contractors' legal team needed to carefully connect a dispute about the nature of a material to an arrangement of forces in the political and legal arena without directly challenging the sovereign interests of the northern state or its Water Commissioners. On its turn, the northern government sought success for the reservoir project as failure could potentially re-open debates on the authority of their own governing institutions-mainly the Water Commissioners, but possibly much more. The Northern Government had used the reservoir to argue for the territorial integrity of their region of the Ulster province, a boundary to maintain Unionist political majority and economic power. Additionally, putting a major source of the capital city's water supply under the territorial control of a potentially hostile neighbour would have left Craig's government vulnerable to demands from the 'Free State. ${ }^{, 80}$ It is unclear whether cancellation could have reopened the boundary dispute or in so doing enabled a new vulnerability which made Northern Ireland unviable. It seems unlikely based on the delayed timing enabling the two crises to slide past each other. ${ }^{81}$ But unionists surely did not want to test this.

Ultimately the resolution enacted happens at several levels. Without being seen to challenge the authority of the northern state or the reputation of the Water Commissioners, the contractors needed to resolve a dispute about nature and this first required the resolution

\footnotetext{
${ }_{80}$ Not everyone had felt boundary change was as inconceivable as Craig and his Government. As early as 1922 the boundary question had been included in contract negotiations leading to a clause making the Commissioners and not the contractor responsible for additional levies by any new owner. PRONI, WAT records, "contract A" (1923). 'The Irish Free State' established as part of the Anglo-Irish treaty of 1921 was the designation given the new government in the south of Ireland.

81 I have suggested this timing was deliberate. Only when the Boundary Commission report was leaked did it become apparent the Silent Valley was not in jeopardy. Then, 5 days subsequent, the contractors initiated legal action on a dispute that had begun while the Boundary Commissioners were still taking evidence and had reached impasse by autumn 1925 .
} 
of subject-object promiscuity at the ontological level. ${ }^{82}$ Sir Lynden's argument, on behalf of the contractors, established dominance at the procedural level of sovereignty suggesting resolution of the dispute at the level of nature (where a water-subsoil 'object' was said to not be dissociable, at least under certain design conditions) should be explored through negotiation. The arbitrator enacted his sovereignty in the form of an award mutually agreed during negotiations. At the level of nature there was merely an agreement to "investigate" for 18 months, but crucially the subject positions of the two parties had been united in order that knowledge would be grounded in one purpose rather than two opposing purposes. The threat to the authority of the Water Commissioners was protected by the political cover story of 'Providence' or nature. This resolution enacted a particular distribution of sovereignty. The interests of the newly formed state of Northern Ireland were protected and an alignment of engineering expertise from the metropolitan centre of the British jurisdiction affirmed. ${ }^{83}$ Every localized performance of state sovereignty may also provide an arrangement of local actors, their interests, and affirmation of their authority. In this case science was relevant to that distribution.

\footnotetext{
$\overline{82}$ Commissioners' or contractor's view of water-earth subsoil divisibility? Is the subsoil one object or two? By what subject position will we act upon the object(s) to determine this?

${ }^{83}$ Precedent: When a particular group of subjects achieve dominance in decision-making, they may be able over time to organize objects in such a way as to reinforce their subject position. At the most subtle level this can be how knowledge is constructed about the nature of materials. Two precedents are perhaps relevant to the negotiations. The very similar Littleton Reservoir controversy, commissioned by the city of London, was cited in the newspapers as a precedent. The Water Commissioners were said to be following the path of the largest water authority in the world and were thus in good company. Dec 161926 News-letter. The other possible precedent for establishing a solution emerges from the engineering experience of Sir Ernest Moir, who had experience in excavation under air pressure first at construction of the Forth Bridge in Scotland, then the largest cantilever bridge in the world, and then as engineer for the subaqueous Hudson river tunnel where he designed the first decompression chamber to treat labourers afflicted with caisson disease. Winchester, C., \& Walley, T. (1939). A similar device was later to be designed, built, and used at the Silent Valley excavation, under the guidance of Sir Ernest Moir. It came to be known as the 'Gazoon' by the workers. McIlldowie (1934), p. 30; Carson (1981), p. 48. Mr. Ernest Moir returned to England to design the (improved) shield and equipment for the Blackwall Tunnel under the Thames, a task which Pearsons had been contracted to do for the London City Council. On this project, the supervising engineer for the city was Alexander Richardson Binnie, father of the arbitrator. Contract and Specification documents, Pearson Archive, Box 67. It is clear that Sir Ernest Moir was familiar with the use of compressed air in excavation work, and it is likely the arbitrator, Mr. William Binnie (of the firm Sir Alexander Binnie, Son, and Deacon) was familiar with Moir's expertise. Here we can see a network of key engineers that all know one another, have offices near one another in Westminster, and their firms build all over the world. This surely facilitates the transfer of solutions from one case somewhere in the world to another with a similar problem. Another fact perhaps sheds a surprising light on the relevance of the Littleton Reservoir dispute to the Silent Valley arbitration. The contractors in the Littleton Reservoir dispute were S. Pearson \& Sons, Ltd. Thus in 1923 when Pearsons were negotiating a contract with the Water Commissioners- the very contract which this article has described in action during arbitration- they were also resolving the Littleton Reservoir dispute! It is quite likely that when they negotiated the contract language, they were considering especially carefully what would protect them if a similar case of uncertainty arose. It seems probable that the powerful and effective interpretation of the original replica contract (with all of its additional record of detail) enabled Sir Lynden Macassey to link these past circumstances with the present ones in such a way that the previous resolution was re-enacted (with one exception: Pearsons now received $2 \frac{1}{2} \%$ for administrative costs at their London office, an improvement which they had failed to specify in the previous case.) It is beyond the scope of this article to look at how such networks of people, conventions and devices help build and maintain the infrastructure and relations of empire, but the multiple geographies, social networks, and precedents here are certainly suggestive for future historical work.
} 
Political histories rarely link legal sovereignty to scientific knowledge and infrastructure technologies. However, in principle science ('laws of nature') and law ('laws of the land') are consonant. The cultural practice of expertise (what I am here calling 'scientific sovereignty') is closely linked to the experimental method, developed by Robert Boyle during the seventeenth century. Perhaps one reason for the acceptance of Boyle's controversial new experimental method was that he explicitly modelled it upon the legal practices used by political authorities. Witnesses were more credible if they were aristocratic, male, and close to the establishment. Those who did not own property were not considered independent and thus could not have an independent or 'modest' opinion. Boyle adopted the legal standards for witnessing from Clarendon's 1661 Treason Act, thus directly tying the power to speak for the nonhuman objects of nature to practices of upholding the sovereignty of the Crown during the English Civil War. ${ }^{84}$ Political theorists such as Giorgio Agamben and Mark Neocleous define sovereignty in its ability to ban or exclude. ${ }^{85}$ As such, state sovereignty and the world-establishing experimental method for determining facts about nature-distinguishing (or banning) subjective opinions from objective knowledge — can be connected. While there is a wide history and sociology of technology literature on the use of expertise, including the use of expertise in courtrooms, it is the approximate line-up of questions of expertise with questions of vital state interest that warrants within this study the additional characterization of a particular role or type of expertise which I designate 'scientific sovereignty'. As a water history, the Silent Valley Reservoir dispute is salient in that a small fledgling state (its sovereignty in question) encountered a state-of-the-art engineering problem in a project aligned to its sovereign interests. Any relation between science and state (each normally appraised at two quite distinct social scales) is in most cases less discernible, more pedestrian.

In summary, the contractors' legal team put the nature of the sub-soil at the foundation of their argument. According to a particular reading of the contract, the Water Commissioners were responsible for errors of design. Because of the sub-soil, the design was said to be unfit for purpose. At the procedural level of sovereignty, Sir Lynden did not have to conclusively resolve the nature of the sub-soil. The nature of the sub-soil (as understood in court) merely had to be delimited to a range of values where it seemed a timber trench would not be practical for excavation. This delimitation was determined by information conflict with charts, diagrams and graphs. To some extent, the material itself as an unpredictable substance lent credibility to the interpretation. The particular arrangement of the facts at this point enabled the contractors to claim their argument and force renegotiation of the legal and financial arrangements for constructing the reservoir. By displacing blame from both themselves and the Water Commissioners onto 'Providence', the contractors achieved the resources and time to pursue a technical solution to the reservoir problem, exploring the role of excavation under increased air-pressure (Fig. 6) until, ultimately, the cut-off trench (braced with iron-cladding) was excavated to bedrock and the first concrete poured in December $1929 .{ }^{86}$ Very little information was provided to the public until this

\footnotetext{
${ }^{84}$ Shapin and Schaffer (1985) Leviathan and the air-pump, p. 327. The penalty for treason to the Crown was most often death.

85 Agamben (1998) and Neocleous (2003).

86 Dec 111929 Telegraph; Dec 121929 Whig, News-letter, Irish News. Actor-networks theory relies upon tracing the existing lines of power that enable what is present in the network. This approach makes it difficult to understand how in certain ways a socio-technical network is made possible by the absences, by what is not present in the network, by unseen exclusions. The following references have all raised similar concerns: Star (1991) "Power, Technologies and the Phenomenology of Conventions: on being allergic to onions" in Law (Ed.) (1991) A sociology of monsters: Essays on power, technology, and domination (No. 38) Routledge, London; Lee and Brown (1994) "Otherness and the Actor Network: the Undiscovered Continent." American Behavioral Scientist 36:772-790; Button "The curious case of the vanishing technology"
} 
point about the embarrassing and uncertain project. But during the final period of completion the site became a symbol of science and good governance with public tours arranged for many local groups and civic officials, including the entire membership of the British Waterworks Association when Belfast took over the presidency of this organisation in 1931. ${ }^{87}$ The inauguration ceremony in May 1932 had 800 invited guests (Fig. 7). Today the 3000-million-gallon reservoir continues to be a major water source for the city of Belfast. Legal dispute procedures about engineering infrastructure were linked to both the macroscale governance concerns of the local state (including its territorial sovereignty) and the quite micro-concern about a decision on the nature of a material (scientific sovereignty).

\section{Discussion}

I have argued at the beginning of this article that certain seemingly contingent moments warrant close examination because, it does indeed seem, the story could have gone differently, perhaps very differently. Since we only ever have one instance of any event, it will always be impossible for the historian to prove empirically that this is so. Thus the action is always to document what did happen as best as possible-as I have done in the above.

I suggest the sovereign might be recognized by the historian not as pre-existing and determining, but as contingent, emergent from a historical process separating subject from object. The subject-object-sovereign triad is historical, contingent. However, over time it may develop some amount of path dependency. When a particular group of subjects achieve dominance in decision-making, they may be able to organize objects in such a way as to reinforce their subject position. At the most subtle level, this can be how knowledge is constructed about the nature of materials. It's worth noting that the sub-soil ultimately was dewatered, so the soil-water 'object' to which Sir Lynden momentarily lends his credibility became the two separate objects of knowledge, soil and water, which the Water Commissioners wanted them to be. Here I sympathise with the perhaps common-sense approach of a contemporary engineer that of course, water and soil are dissociable(!), and the (perhaps accurate?) suspicion that Sir Lynden lingers on ambiguity for performative reasons of legal strategy. ${ }^{88}$ But power relations in the court case opened up a temporary space of ambiguity long enough for the dominant parties to align their subject interests (partly in relation to sovereignty and partly as a localized construction of sovereignty) so as to agree upon what the object/objects were, i.e. dissociable/indissociable, both in the circumstances of design

\footnotetext{
Footnote 86 (continued)

in Button (1993). Technology in working order: Studies of work, interaction, and technology. Routledge, London. Some of the original authors of actor-network theory have attempted to summarise and work with these critiques in Callon and Law (1995) "Agency and the Hybrid Collectif" South Atlantic Quarterly 94:481-507. A general critique of networks as a metaphor is given by Marilyn Strathern, in Strathern (1996) "Cutting the network" Journal of the Royal Anthropological Institute, 517-535. In this water history I emphasize the blame regime 'Providence', or nature, to show what must also be hidden or absent for the reservoir to be completed.

87 July 201931 Daily Express.

88 Nor is this a historical argument. Water and soil were also dissociable in 1926. For interesting early engineering commentary on similar soil properties see Schuyler (1907) "Recent Practice in Hydraulic Fill Dam Construction," Transactions of the American Society of Civil Engineers 58:196-277 available at https:// archive.org/details/transactionsofam58amer/page/n257.
} 


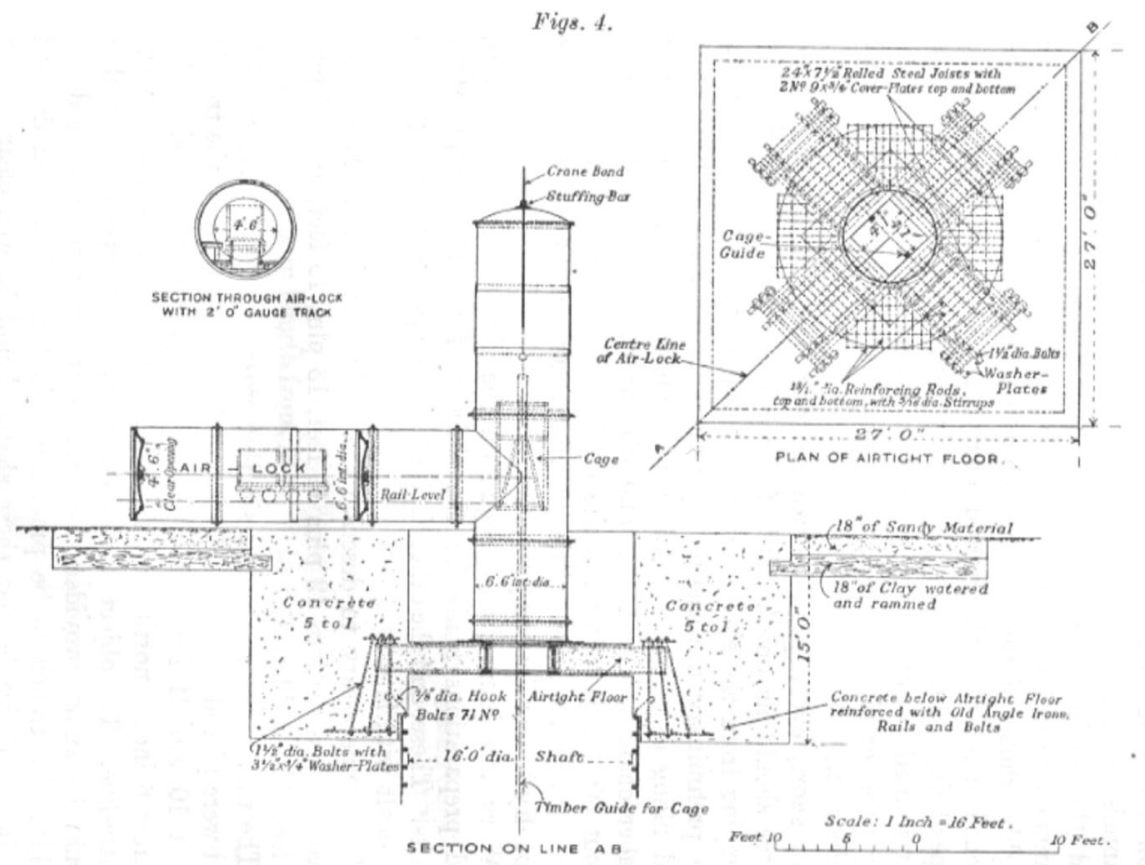

Air-lock at Head of Exploratory Shaft.

Fig. 6 Plan of the Air-shaft device. The fluid materiality of the subsoil was addressed by compressed air technology. The device was able to be developed only after resolution of the contract dispute. Source: McIldowie, p10

by timber-line trench and of design by cost plus percentage (within an iron-lined trench and excavated under air-pressure). Using only common-sense in an uncommon situation can be expensive.

I proposed a water history through the particular nuances of a contract arbitration. ${ }^{89}$ It is precisely because engineering practice and scientific knowledge become standardized that they are so easily written out of political histories. We can write them back in by telling

\footnotetext{
${ }^{89}$ Where to Start? Device, Social Convention or Choice: By way of alternative starting point, consider how an actor-networks theory account of the airshaft device might be used to tell the story of the Silent Valley Reservoir. The airshaft device allows the reservoir to become state infrastructure; But only after dispute resolution as a point of passage required to provide the time and resources necessary, can the airshaft device be developed. Thus, the actor-network describing the air-shaft device (the sought topological relationship between device shape and social/political forces) would actually need to be extended to include the construction contract and practices related to enforcing this. The immediate shape of the device is not particular to the sovereignty question. While such extended topology, air-shaft qua contract device, is perfectly legitimate (for example, Bruno Latour has described scientific papers as immutable mobiles: a fixed relationship of words, sentences, diagrams, circulating through research communities; Mark Suchman has extended this materiality-of-the-document approach to legal contracts), the sought-after relationship is easily divided by describer into social convention and technical convention without making visible the link between them, an activity Bruno Latour describes as the 'work of purification' where the social and the technical are habitually divided in our practices of identification, interpretation, and speech. While more broadly it is an interesting question the link between contract clause convention and problem-resolving technical devices, in this
} 


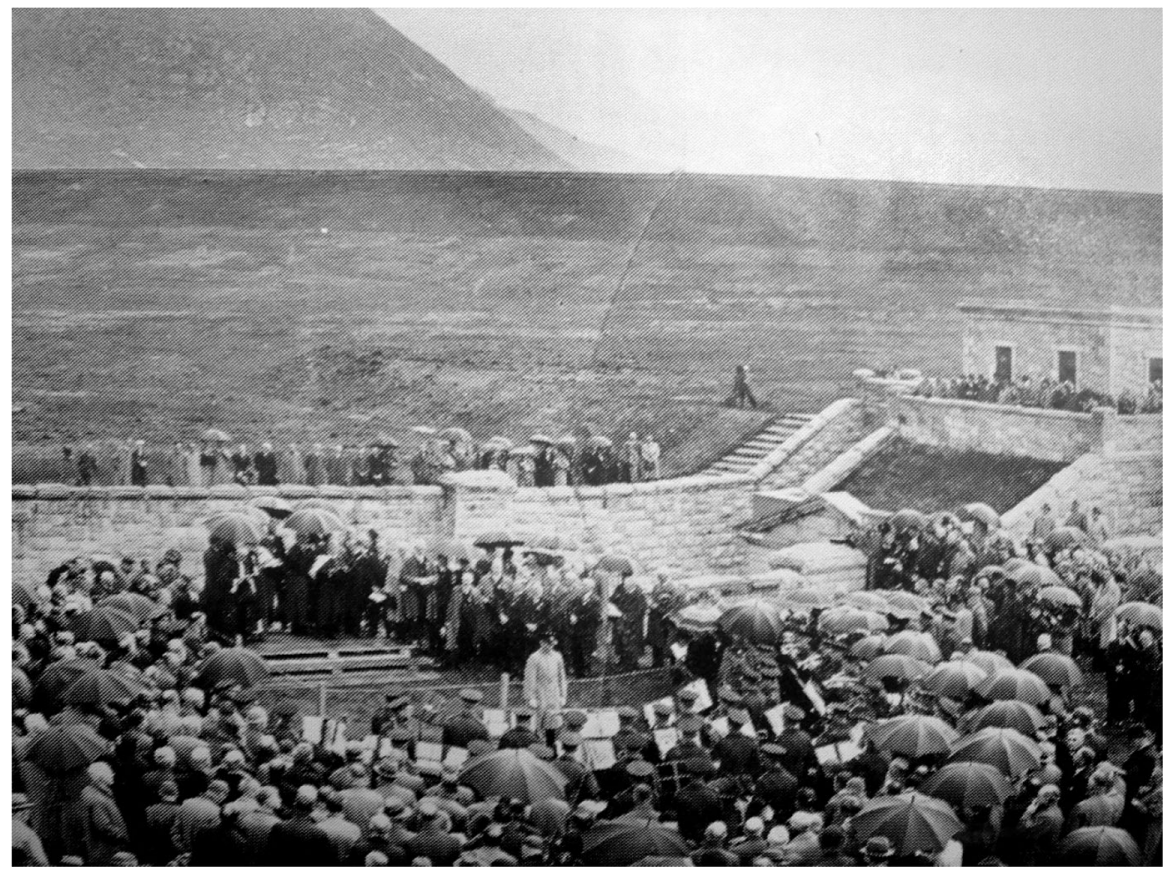

Fig. 7 Innauguration of the Reservoir. May 24, 1932. The hymn "O God, our help in ages past" was accompanied by the Regimental Band of H.M. 1st Battalion the Border regiment, followed by prayers and readings from the Old and New Testaments by a variety of protestant religious leaders. Perhaps fortuitously for a ceremony held in a catchment valley, umbrellas indicate rain from the heavens. Source: Pearson Archive

histories of how these knowledge practices became standardized. Sometimes these practices have become physically standardized as material objects, instruments, or technologies with interchangeable standardized parts. ${ }^{90}$ And sometimes these practices have become socially standardized in conventions of use or dispute resolution, for example, contract. Socio-legal scholar Mark Suchman has extended a materiality-of-the-document approach to legal contracts by emphasizing "(1) the microdynamics of why and how transacting

\section{Footnote 89 continued}

specific example (which I present as micro-history rather than case study within a larger paradigm) the airshaft device function does not repetitively invoke the contract in order to excavate. Rather, it does so only once- as a point of passage. So I have chosen in this article to emphasize the element of human choice and performance within a contingent situation. This liberates the creative use of social conventions and material devices to resolve dispute and build a reservoir. For the work of purification, see Latour (1993) We have Never been Modern London: Prentice Hall. For early (pre)actor-network publications, where a point of passage rather than resolution from an open social topology is seen to enable/disable the technological device, see Callon and Law (1992), 'The Life and Death of an Aircraft: a Network Analysis of Technical Change', in John Law and Wiebe Bijker (eds), Shaping Technology-Building Society: Studies in Sociotechnical Change, Cambridge, Mass.: MIT, pp. 21-52. For a more recent approach to the same material see Law (2002), Aircraft Stories: Decentering the Object in Technoscience, Durham, North Carolina, Duke University Press, particularly wind gust factor research.

90 For example, see Marsden and Smith (2005) Engineering Empires. 
parties craft individual contract devices, and (2) the macrodynamics of why and how larger social systems generate and sustain distinctive contract regimes." 91

We can also write them back in by finding curious moments in the breakdown of routine structure where the fabric of social relations struggling to put itself back together can be seen. It is often these moments which seem most contingent because skilled (or unskilled) social actors must navigate some absence of technical and social convention. The unique coincidence of a water engineering crisis temporally contingent to the recent and still formulating partition of Ireland is one such moment within which the torn fabric of social relations can be seen being reconstituted within a legal, engineering, and scientific dispute. In this moment, by following the legal, scientific, and political positioning of social actors, the usually invisible connection of science and sovereignty becomes discernible to the historian in the performative allocation of engineering judgement within legal judgement, when engineer-arbitrator is asked to decide the fate of the nature of a material.

\section{Archival sources}

Pearsons Collection, The Science Museum Library and Archives at Wroughton.

Water Commissioners' Papers, WAT/1, Public Record Office of Northern Ireland (PRONI), Titanic Boulevard, Belfast.

Note on periodicals-Irish News, Belfast Telegraph, Ulster News-letter, Northern Whig, Daily Mail: Newspapers were accessed through 'Newspaper Clippings' located in the WAT/1 archive at the Public Record Office of Northern Ireland. The following records contained newspapers from the following dates:

WAT/1/3F/3/5 1916-1926

WAT/1/3F/3/6 1927-1929

Although not paginated, these books are organized chronologically, thus date and name of the newspaper (when given) serves to locate references.

Open Access This article is licensed under a Creative Commons Attribution 4.0 International License, which permits use, sharing, adaptation, distribution and reproduction in any medium or format, as long as you give appropriate credit to the original author(s) and the source, provide a link to the Creative Commons licence, and indicate if changes were made. The images or other third party material in this article are included in the article's Creative Commons licence, unless indicated otherwise in a credit line to the material. If material is not included in the article's Creative Commons licence and your intended use is not permitted by statutory regulation or exceeds the permitted use, you will need to obtain permission directly from the copyright holder. To view a copy of this licence, visit http://creativecommons.org/licenses/by/4.0/.

\section{References}

Agamben G (1998) Homo sacer: sovereign power and bare life. Stanford University Press, Stanford Arnold D (2013) Everyday technology: machines and the making of India's modernity. University of Chicago Press, Chicago

Ballaestro A (2019) A future history of water U.S.A. Duke University Press, Durham

${ }^{91}$ Suchman (2003) "The Contract as Social Artifact” Law \&Society Review 37/1:91-142, p. 91. 
Benton L (2009) Search for sovereignty: law and geography in European empires, 1400-1900. Cambridge University Press, Cambridge

Bew P, Gibbon PJ, Patterson HH (1979) The State in Northern Ireland 1921-72: political forces and social classes. Manchester University Press, Manchester

Broich J (2013) London: water and the making of the modern city. University of Pittsburgh Press, Pittsburg

Brown J (1997) Preface. In: Jackson D (ed) Dams: studies in the History of civil engineering, vol 4. Ashgate, Brookfield

Burke P (2005) Performing History: the importance of occasions. Rethink Hist 9(1):35-52

Button G (1993) The curious case of the vanishing technology. In: Button G (ed) Technology in working order: studies of work, interaction, and technology. Routledge, London

Callon M (1986) Some elements of a sociology of translation: domestication of the scallops and the fishermen of St Brieuc Bay. In: Law J (ed) Power, action, and belief. Routledge, London

Callon M, Law J (1992) The life and death of an aircraft: a network analysis of technical change. In: Law J, Bijker W (eds) Shaping technology_building society: studies in sociotechnical change. MIT, Cambridge, pp 21-52

Callon M, Law J (1995) Agency and the hybrid collectif. South Atl Q 94:481-507

Carrol P (2006) Science, culture, and modern state formation. University of California Press, Berkeley and Los Angeles

Carroll-Burke P (2002) Material designs: engineering cultures and engineering states-Ireland 1650-1900. Theory Soc 31(1):75-114

Carson WH (1981) The dam builders: the story of the men who built the Silent Valley Reservoir. Mourne Observer Press, Newcastle

Conduit CW (1973) Review: A History of dams. Technol Cult 14(4):621-622

Cookson-Hills C (2013) The Aswan Dam and Egyptian Water Control Policy, 1882-1902. Radic Hist Rev 116:59-85

Deleuze G, Guattari F (1987) A thousand plateaus. Minneapolis University Press, Minneapolis, London

Dikkotter F (2007) Things modern: material culture and everyday life in China. Hurst, London

Dobraszczyk P (2008) Image and audience: contractual representation and London's main drainage system. Technol Cult 49:3

Donald PTA (2012) The Silent Valley dam: setting the record straight. Eng Hist Herit 165(EH2):81-92. https://doi.org/10.1680/ehah.11.00014

Dudley M (2019) The limits of power: wind energy, Orkney, and the post-war British State. Twent Century Br Hist. https://doi.org/10.1093/tcbh/hwz024

Edgerton D (2007) Global Histories: rethinking now, travel in space and time. J Hist Sci Technol 1:75-112

Ertsen M (2010) Locales of happiness: colonial irrigation in the Netherlands East Indies and its remains, 1830-1980. VSSD, Delft

Ertsen M (2011) Book reviews. Water Hist 3(1):63-66

Ertsen M (2016) A matter of relationships: actor-networks of colonial rule in the Gezira irrigation system, Sudan. Water Altern 9(2):203-221

Fligstein N, McAdam D (2012) A theory of fields. Oxford University Press, Oxford, New York

Garfinkle H (1967) Studies in ethnomethodology. Prentice Hall, Cornwall

Gilmartin D (2015) Blood and water: the indus river basin in modern history. University of California Press, Oakland

Ginsberg C (1993) "Two or three things I know about microhistory" translated Tedeschi \& Tedeschi. Crit Inq 10(1):10-35

Hill J Jr (2017) Circuits of state: water, electricity, and power in Chihuahua, 1905-1936. Radic Hist Rev 127:13-39

Hopkinson M (1990) The Craig-Collins Pacts of 1922: two attempted reforms of the Northern Ireland government. Ir Hist Stud 27(106): 145-158

Hundley NJ (1975) Water and the west: The Colorado River compact and the politics of water in the American West. University of California Press, Berkeley

Hundley NJ (1992) The great thirst: Californian water 1770s-1990. University of California Press, Berkeley Jackson D (1995) Review: a history of dams. Technol Cult 36(1):179-180

Jessop B (1990) Recent theories of law, the state, and juridico-political ideology. In: Jessop B (ed) State theory: putting the capitalist state in its place. Polity Press, Cambridge, pp 48-78

Knor-Cettina K (1981) Advances in social theory and methodology: toward an integration of micro- and macro-sociologies. Routledge and Kegan Paul, Boston, London and Henley

Latour B (1993) We have never been modern. Prentice Hall, London

Latour B (1999) Pandora's hope: essays on the reality of science studies. Harvard University Press, Cambridge, London 
Law J (Ed) (1986) Power, Action, and Belief. London: Routledge

Law J (1987) Technology and heterogeneous engineering: the case of portuguese expansion. In: Bijker WE, Hughes TP, Pinch TJ (eds) The social construction of technological systems: new directions in the sociology and history of technology. MIT Press, Cambridge

Law J (1992) Notes on the theory of the actor-network: ordering, strategy, and heterogeneity. Syst Pract 5:179-393

Law J (2002) Aircraft stories: decentering the object in technoscience. Duke University Press, Durham

Law J, Ruppert E (2013) The social life of methods: devices. J Cult Econ 6(3):229-240

Lee N, Brown S (1994) Otherness and the actor network: the undiscovered continent. Am Behav Sci $36: 772-790$

Linton J (2010) What is water: the history of a modern abstraction. UBC Press, Vancouver

Loudon J (1940) In search of water: being a history of the Belfast water supply. Belfast City and District Water Commissioners, Belfast

MacLeod R (1997) On science and colonialism. In: Bowler PJ, Whyte N (eds) Science and society in Ireland: the social context of science and technology in Ireland 1800-1900. Belfast Institute of Irish Studies, QUB, Antrim

Marsden B, Smith C (2005) Engineering empires: a cultural history of technology in nineteenth century Britain. Palgrave Macmillan, Basingstoke

Martin JL (2011) The explanation of social action. Oxford University Press, New York

Mathews K (2004) Fatal influence: the impact of Ireland on British politics, 1920-1925. University College Dublin Press, Dublin

McIldowie G (1934) The construction of the Silent Valley Reservoir, Belfast water-supply. The Institution of Civil Engineers, London

Mori L (2020) Water and power: what is left? An introduction to the workshop Waterscapes: new perspectives on hydrocultural landscapes in the ancient Near East. Water History 12(1):11-22. https://doi.org/ 10.1007/s12685-020-00246-4

Mukerji C (1994) The political mobilization of nature in seventeenth century French formal gardens. Theory Soc 23(5):651-677

Mulcahy L (2008) Contract law in perspective, 5th edn. Routledge-Cavendish, New York

Murray P (2004) Partition and the Irish Boundary Commission: a northern nationalist perspective. Clogher Record 18(2):181-217. https://doi.org/10.2307/27699506

Murray P (2011) The Irish boundary commission and its origins, 1886-1925. University College Dublin Press, Dublin

Neocleous M (2003) Imagining the state. Open University Press, Maidenhead, Philadelphia

Neville J, Douglas H, Compton PA (1992) The Northern Ireland-Irish Republic Boundary. Espace, Populations, Sociétés, 1992-2 Population et frontières-Population and frontiers. https://doi.org/10.3406/ espos.1992.1526

O'Callaghan M (2000) "Old Parchment and Water"; the Boundary Commission of 1925 and the Copper fastening of the Irish Border. Bullan Ir Stud J 5(2):27-55

Pinch T, Bijker W (1984) The social construction of facts and artifacts. Soc Stud Sci 14:399-441

Rankin K (2007) Deducing rationales and political tactics in the partitioning of Ireland, 1912-1925. Polit Geogr 26(8):909-933

Reuss M (2008) Seeing like an engineer: water projects and the mediation of the incommensurable. Technol Cult 49(3):531-546

Schmidt J (2017) Water: abundance, scarcity and security in the age of humanity. New York University Press, New York

Schmitt C (1985) Political theology: four chapters on the concept of sovereignty. MIT University Press, Cambridge

Schnitter NJ (1994) A history of dams: the useful pyramids. A. A. Balkema, Rotterdam

Schuyler James D (1907) Recent Practice in Hydraulic Fill Dam Construction. Trans Am Soc Civ Eng 58:196-277. Available at https://archive.org/details/transactionsofam58amer/page/n257

Shapin S, Schaffer S (1985) Leviathan and the airpump: Hobbes, Boyle and the experimental life. Princeton University Press, Princeton

Smith N (1972) A history of dams. Citadel Press, Seacaucu

Smith N (1975) Man and water: a history of hydro-technology. Scribner's Sons, New York

Soll D (2013) Empire of water. Cornell University Press, Ithaca, London

Star SL (1991) Power, technologies and the phenomenology of conventions: on being allergic to onions. In: Law J (ed) A sociology of monsters: essays on power, technology, and domination, vol 38. Routledge, London

Strathern M (1996) Cutting the network. J R Anthropol Inst 2:517-535 
Suchman M (2003) The contract as social artifact. Law Soc Rev 37(1):91-142

Templehoff J, Hoag H, Ertsen M, Arnold E, Bender M, Berry K, Fort C, Pietz D, Musemwa M, Nakawo M, Ur J, van Dam P, Melosi M, Winiwarter Verena, Wilkinson Tony (2009) Where has the water come from? Water Hist 1(1):1-8

Tolstoy L (1984 [1894]) The kingdom of god is within you: christianity not as a mystic religion but as a new theory of life (C. Garnett, Trans.). University of Nebraska Press, Lincoln

Tvedt T (2015) Water systems, water agreements and state sovereignty: the case of the Nile Waters Agreement of 1929. In: Tvedt T, McIntyre O, Woldetsadik TK (eds) A history of water series III, Volume 2, sovereignty and international water law. I.B. Tauris, London, New York

Tvedt T, McIntyre O, Kasse T (2015) Sovereignty, the web of water and the myth of Westphalia. In: Tvedt T, McIntyre O, Woldetsadik TK (eds) A history of water series III, Volume 2, sovereignty and international water law. I.B. Tauris, London, New York

Verhoeven H (2015) Water, civilization and power in Sudan: the political economy of military-islamist state building. Cambridge University Press, Cambridge

Weber M (2004 [1919]) Politics as a vocation. In: Owen D, Strong TB (eds) Max weber: the vocation essays: "science as a vocation", "politics as a vocation". Hackett, Indianapolis

Wheeler S (2005) Feminists perspectives in contract law. Taylor and Francis, London

White R (1995) The organic machine: the remaking of the Columbia River. Hill and Wang, New York

Whyte N (1997) Science and nationality in Edwardian Ireland. In: Bowler PJ, Whyte N (eds) Science and society in Ireland: the social context of science and technology in Ireland 1800-1900. Institute of Irish Studies, QUB, Belfast

Winchester C, Walley T (1939) Tunneling the hudson. In Winchester C, Walley T (ed) Wonders of world engineering: Epics of conquest in story and picture. London: Amalgamated Press. Also available at https://www.wondersofworldengineering.com/hudson.html

Wittfogel K (1957) The despotic state: a comparative study in total power. Yale University Press, New Haven

Worster D (1985) Rivers and empire: water, aridity, and the growth of the American West. Pantheon, New York

Worster D (1997) Hoover dam: a study in domination. In: Jackson D (ed) Dams: studies in the history of civil engineering, vol 4. Ashgate, Brookfield, pp 337-354

Publisher's Note Springer Nature remains neutral with regard to jurisdictional claims in published maps and institutional affiliations. 